\title{
Expositio tituli
}

Only to these worthy people should the dignity of wisdom contained in this Theological Elementation be uncovered. And so are they led into these theorems as into a certain byway that is beyond the common path of reasonings. ${ }^{1}$

Berthold's Expositio tituli is an analysis of the incipit of the Elementatio theologica according to the four causes (efficient, material, formal, and final). Like the Prologus, it is a sophisticated example of a traditional literary form, in this case the accessus ad auctorem. ${ }^{2}$ Berthold's accessus can be categorised, following the taxonomy of Richard Hunt, as a "type C" introduction, which treats some combination of a text's intentio, materia, finis, modus agendi (ordo), nomen auctoris, titulus, or utilitas. ${ }^{3}$ By the mid-12th century this kind of introduction was commonly employed. ${ }^{4}$ The Aristotelianised version modelled on the four causes and adopted here by Berthold developed from it. ${ }^{5}$ Berthold would have encountered several examples of this, probably in the work of Nicholas Trevet in Oxford and certainly in Albert the Great's commentaries on Scripture and

1 Berthold of Moosburg, Expositio, Expos. tit. K, p. 48, 1. 390-393: Hi soli digni sunt, ut eis sapientiae, quae in ista Elementatione theologica continetur, dignitas exeratur; et ideo in quoddam quasi diversorium extra publicam rationem viam in ista theoremata perducuntur. Cf. Gilbert of Poitiers, Expositio in Boecii librum de bonorum ebdomade, ed. N. Häring, The Commentaries on Boethius by Gilbert of Poitiers (Toronto: Pontifical Institute of Medieval Studies, 1966), prol., $§ 7$, p. 184, l. 32-38. The literal rendering of Elementatio theologica in my translations of Berthold follows from his speculations about the meaning of the title in Expos. tit. I-K.

2 See A.J. Minnis, Medieval Theory of Authorship. Scholastic Literary Attitudes in the Later Middle Ages (Aldershot: Wildwood, 1988²), p. 40-58, and Dahan, "Les prologues", p. 433-438.

3 R. Hunt, "The Introductions to the Artes in the Twelfth Century", in Studia mediaevalia in honorem R.J. Martin (Brugge: De Tempel, 1948), p. 84-112.

4 N. Häring, "Commentary and Hermeneutics", in R. Benson, G. Constable (eds), Renaissance and Renewal in the Twelfth Century (Oxford: Clarendon Press, 1982), p. 173-200, at p. 185-19o.

5 Minnis, Medieval Theory of Authorship, p. 9-39 and 76. 
on the Dionysian corpus. ${ }^{6}$ Like Albert and Nicholas, Berthold placed his accessus ad auctorem after a "sermon-type" prologue.

The Expositio tituli took the broader discussion of the Hermetic macrocosm and microcosm from the Prologus, and the diagnosis of the human condition it implied, and presented Proclus as the exemplary divine man whose texts can lead the desirous soul to the vision of God. In this second preface, Thomas of York and his discussion of pagan knowledge of the universe and God continued to be a major source for Berthold, especially in his analyses of the text's efficient cause (Proclus himself and the ways by which he came to know God) and the final cause (the goal of the Elementatio is to bring to fruition the innate desire for beatifying wisdom). As for the material cause of the Elementatio theologica, Berthold now looked to another German Dominican source, Dietrich of Freiberg, and his version of the distinction of natural and voluntary providence, which Ulrich of Strassburg had first developed from Augustine's De Genesi ad litteram. Dietrich's doctrine of the intellectus adeptus will also be taken up by Berthold as he articulated the precise stages of the contemplative life that Proclus fully realised. Finally, regarding the formal cause or structural principle of the Elementatio, Berthold drew upon Boethius and the 12th-century commentary tradition on his De Trinitate and De hebdomadibus, for their account of why theology should proceed according to a theorematic form.

\section{Plato's Theorems}

The seeds for Berthold's discussions of the efficient and formal causes were sown in the miniature history of the Platonic tradition that opened the Expositio tituli:

Proclus exceeded by far [procul excellebat] all the followers of Plato and thus surpassed everyone in ability [praepollebat], such that there emanated forth from him most of all, as it once had from Plotinus, 'the very voice of Plato,' which, as Augustine attests in Book 3 of Against the Academicians, 'is the purest and most lucid in all of philosophy, after the clouds of error have been cleared away' and all the coverings [integumentis], with which the first Platonists and especially the Academicians had

6 On Nicholas, see Lord, "Virgil's Eclogues", p. 198 and 204. On Albert, see Dahan, "Les prologues", p. 437-439. 
concealed Plato's wisdom. For it was customary among them, as Cicero says and Augustine recounts in the same work, 'to conceal his doctrine and not reveal it to anyone, except to those who had lived with them up to old age'. And thus Proclus, like Plotinus, as is recounted in the same text, 'was deemed to be so similar' to Plato 'that one would have supposed that they lived at the same time; but since so many centuries had elapsed, one had to suppose that Plato was reborn in him.?

In this brief history, Berthold combined two separate passages in Augustine's Contra Academicos and, in so doing, drastically altered their original meaning, because he associated Cicero's report about concealment within the Academy (for Augustine this concerned the avowed skepticism of the Academy which, in his view, hid a more positive form of knowledge) with Augustine's own verdict about the errors that accrued to Plato's doctrines over the centuries, until Philo and, finally, Plotinus regained their pristine origin. ${ }^{8}$ In Berthold's rendering, any interpretation of Plato that would take the myths literally has not reached the esoteric truth of Plato's teaching.

Berthold's reasons for reading Augustine in this way have to do with his more fundamental assumptions about the ideal method and goal of theology. These assumptions only become apparent over the course of the Expositio

7 Berthold of Moosburg, Expositio, Expos. tit. A, p. 37, 1. 14-24: Ipse enim omnes Platonis sectatores procul excellebat et in philosophia sic omnibus praepollebat, ut emicaret maxime in eo sicut et in Plotino 'os illud Platonis, quod - sicut testatur Augustinus III libro Contra Academicos - in philosophia purgatissimum est et lucidissimum demotis nubibus erroris' et integumentis omnibus, quibus Platonici primi et maxime Academici suam sapientiam obvolvebant. Mos enim fuit eis, ut dicit Cicero, prout recitat Augustinus ubi supra, 'occultandi sententiam suam nec eam cuiquam, nisi qui secum ad senectutem usque vixisset, aperire consueverunt'. Ita enim ipse Proclus sicut et Plotinus, prout recitatur ibidem, Platonis similis iudicatus est, ut simul eos vixisse, tantum autem interest temporis, ut in hoc ille revixisse putandus sit.' Cf. Augustine, Contra Academicos, III.18.41 and III.20.43. For a complete picture of Berthold's understanding of the Platonic tradition, see also Expos. tit. G-H, p. 43, l. 212 - p. 45, l. 275.

8 As we will see later in Berthold's criticism of Macrobius and Proclus on reincarnation, Berthold seems to have thought of these coverings (integumenta) in terms of mythical fables. In his glosses on Macrobius, he copied William's statement that pagan myths were integumenta which concealed philosophical truth. In Ms Basel, Universitätsbibliothek, F.IV.31, In Somn. Scip., I.2.17, f. 4V: SED QVIA SCIVNT INIMICAM ESSE NATVRAE APERTAM NVDAMQVE EXPositionem SVI. Si quis enim diceret rusticis quid re vera sit Ceres et alia que de ea sub integumentis figurantur, scilicet quod Ceres non est aliud quam naturalis vis terre producendi segetes. Item quod non alia de causa nec aliter vannus ei adtribuitur nisi quod pertinet ad purgationem frumenti nullum incuteret eis terrorem. On the theory of integumenta, see É. Jeauneau, "L'usage de la notion d'integumentum à travers les gloses de Guillaume de Conches", in Archives d'histoire doctrinale et littéraire du Moyen Âge 24(1957), p. 35-100. 
tituli. We glimpse them already in Berthold's description of the two causes of Proclus' excellence or, in other words, the two ways in which the voice of Plato spoke through him. First was the fact that "he gave order to Plato's very own theorems in the present book". The notion that Plato originally transmitted his philosophy in theorems (theoremata) seems to have been, in part, based on Berthold's extrapolation of a remark made by Eustratius that "Plato passed on theorems concerning the first Good that are above contempt". ${ }^{9}$ In his revision of Augustine's history, then, Berthold wanted us to understand that Plato's originally theorematic philosophy was transmitted secretively in the Academy, concealed with mythical coverings, and was eventually restored in its definitive form, first by Plotinus, and then by Proclus in the Elementatio theologica. ${ }^{10}$ This achievement is directly related to the second cause of Proclus' excellence, which is discussed at length momentarily. This consisted in the fact that, as the Tria opuscula attest, Proclus exhaustively traversed the three spiritual motions of the soul described by Dionysius. The Elementatio theologica represented only one of these motions. ${ }^{11}$

In addition to Eustratius' passing remark, in his account of the first cause of Proclus' excellence Berthold evidently had in mind a tradition of theology that associated the theorematic method with secrecy. This tradition went back to Boethius' De hebdomadibus and was invoked later in the Expositio tituli. ${ }^{12}$ The De hebdomadibus was structured with a prologue followed by seven propositions, which served as the rules (regulae) for the remainder of Boethius' argument explaining how created substances are good in virtue of their very existence without being substantial goods. In his prologue, Boethius mentioned two kinds of "common conceptions of the mind": the truth of some common conceptions is self-evident and is acknowledged immediately by whoever understands the terms, while the truth of other common conceptions

Berthold of Moosburg, Expositio, Expos. tit. A, p. 37, 1. 26-29. See S. Gersh, "Berthold of Moosburg, Nicholas of Cusa, and Marsilio Ficino as Historians of Philosophy", forthcoming. Berthold held that Augustine was familiar with this esoteric tradition. In Thomas of York (Sapientiale, lib. I, c. 16), he would have found some of Augustine's descriptions of God distilled into a theorematic form. Thomas made the same reduction with descriptions of God coming from the pagan sapientes mundi (lib. I, c. 17), before beginning a commentary on the Liber XXIV philosophorum (lib. I, c. 18). This was anticipated at Sapientiale, lib. I, c. 1, cited by Berthold at Expos. tit. E (p. 41, l. 163-166), where Thomas stated that Augustine recited Plato's propositions (propositiones Platonis, quas recitat Augustinus), and gave examples of the theorems (Deus est lumen omnium; Deus est veritatis illustrator, etc.) that would reappear in Sapientiale, lib. I, c. 16.

11 Berthold of Moosburg, Expositio, Expos. tit. A-D, p. 37, l. 30 - p. 41, l. 147.

12 Berthold of Moosburg, Expositio, Expos. tit. K, p. 47, l. 343 - p. 49, l. 407. 
is recognised only by those who have received prior training. The seven regulae would belong to this second category. As Boethius explained, the theorematic method is useful both as a personal aid to memorisation and private contemplation, and as a way of warding off ridicule or misunderstanding by the unlearned. Since the obscurity of brevity is itself "the faithful guardian of a secret", the theorems will speak only to those who are worthy to receive them. ${ }^{13}$ The commentary of Gilbert of Poitiers on the prologue of De hebdomadibus, also cited by Berthold, described this secrecy in terms of veiling and unveiling: these theorems of Boethius' treatise, or for Berthold the propositions of the Elementatio theologica, should be revealed only to those who "are less carried away by the fickleness of praise than attracted by the most longed-for, unveiled image of truth itself" (veritatis ipsius revelata desiderantissimaque imagine). Only to the worthy (digni) should the worthiness (dignitas) of the theorems be uncovered (exeratur). ${ }^{14}$ Boethius therefore belonged to the same Platonic tradition described by Augustine, with its use of coverings and its custom of secrecy. Here, however, the propositional form was the veil, not the mythical integumenta. Berthold evidently judged that the difficulty of propositional theology was enough to deter any who do not resolutely desire the truth.

Berthold's interpretations of Augustine and Gilbert were finally brought together using Boethius' programmatic remark in the De Trinitate: "In physics one must apply oneself rationally, in mathematics scientifically, and in theology intellectually, not being led astray by imaginings, but rather by looking into the Form itself, which is a true form and not an image."15 One must turn away from the multiplicity of images, to which our thinking inclines, and look to the single Form or unified image of the truth. The truth of intellect, so we are to understand, is expressed in propositions, whose apprehension requires the abandonment of images. It was this Boethian tradition, projected back onto Augustine's history of Platonism that was corroborated by Eustratius, that led Berthold to regard the Elementatio theologica as a kind of spiritual exercise that leads the mind along "a certain byway beyond the common path of reasonings

13 Boethius, Quomodo substantiae in eo, quod sint, bonae sint, cum non sint substantialia bona, ed. C. Moreschini, p. 186, l. 11 - p. 187, 1. 14: Prohinc tu ne sis obscuritatibus brevitatis adversus, quae cum sint arcani fida custodia tum id habent commodi, quod cum his solis qui digni sunt conloquuntur. See also J.-L. Solère, "L'ordre axiomatique comme modèle d'écriture philosophique dans l'Antiquité et au Moyen Âge", in Revue d'histoire des sciences 56/ 2(2003), p. 323-345, at p. 328-334.

14 Berthold of Moosburg, Expositio, Expos. tit. K, p. 48, l. 388-391.

15 Berthold of Moosburg, Expositio, Expos. tit. K, p. 48, l. 394-398. The compatibility of such a view with that of Moses Maimonides was not lost on Berthold, who cited the parable of the king (Dux neutrorum, lib. III, c. $5^{2}$ ) at precisely this point. 
[extra publicam rationum viam]". ${ }^{16}$ Along with Hermes Trismegistus (of the Liber XXIV philosophorum), Plato, and Boethius, then, the Elementatio theologica stood as the greatest representative of a venerable tradition of theorematic theology. ${ }^{17}$ The Liber de causis, however, along with other treatises purported to have discussed similar material, was relegated by Berthold to a rank definitively inferior to the Elementatio theologica. ${ }^{18}$

\section{The Three Motions of the Soul}

For Berthold of Moosburg, Proclus' achievement in the tradition of theorematics perfected only one of the three possible paths or "motions" by which the soul could come to know God. Berthold would have us view the Elementatio theologica as a kind of philosophical rite of passage, by recalling us to the fact that Proclus, as the Tria opuscula show, had gone even further. The discursive knowledge of God attained in the Elementatio was not seen by him as an end in itself but as a ladder to a higher goal.

In De divinis nominibus 4.8-9 (704D-705B), Dionysius spoke of three motions exercised both by souls (circular, direct, spiral), as they ascend to God, and by angels, in their knowledge of God and their providential operations. In Thomas of York's Sapientiale (lib. I, c. 6), this remark was unfolded into a generalised theory about the three ways the pagans ascended to a knowledge of God. Inspired by Thomas, Berthold then applied this model directly to Proclus and the three ways he ascended to the knowledge of the highest Good by the

16 See also D. O'Meara, "La science métaphysique (ou théologie) de Proclus comme exercise spirituel", in A.-P. Segonds, C. Steel (eds), Proclus et la théologie platonicienne. Actes du Colloque International de Louvain (13-16 mai 1998) en l'honneur de H.D. Saffrey et L.G. Westerink (Leuven: Leuven University Press, 2000), p. 279-29o.

17 Berthold used other theorematic works in the Expositio. He was directly familiar with Alan of Lille's Regulae caelestis iuris (Expos. tit. K, Praeamb. A, 21D, 21F, 176 commentum). He seems to have known Nicholas of Amiens' De arte catholicae fidei through Thomas of York $(7 \mathrm{E}, 9 \mathrm{~B}, 11 \mathrm{~F}, 12 \mathrm{E}, 18 \mathrm{D}, 20 \mathrm{~A}, 35 \mathrm{~B}, 137 \mathrm{E}, 15 \mathrm{oB}, 15 \mathrm{OD}, 162 \mathrm{D}, 168 \mathrm{~B})$. Berthold also knew first-hand the Liber de intelligentiis of Adam Pulchrae Mulieris (Prol. 19, 21E, 36C, 36E, 143K, 143L, 183A), which he sometimes attributed to Alan (Prol. 19, 143K), but elsewhere he expressed his uncertainty about the attribution he found in the manuscript (183A, p. 236, l. 8o-81: libellus De intelligentiis intitulatus, nescio, cuius auctoris, libet ascribatur Alano), perhaps because the Liber cited Alan by name. See the Liber de intelligentiis, ed. C. Baeumker, Witelo. Ein Philosoph und Naturforscher des XIII. Jahrhunderts (Münster i.W.: Aschendorff, 1908), prop. 20, p. 26, 1.15-17.

18 Cf. Berthold of Moosburg, Expositio, Expos. tit. K, p. 48, 1. 401 - p. 49, l. 407, cited at Introduction, section 3, n. 153, above. 
natural light of intellect (Expos. tit. B-D): the circular motion is introspective; the direct motion is an immediate ascent from creatures to "the direct vision of God"; the oblique motion uses "common notions" and discursive reasoning. ${ }^{19}$

To have a complete picture of Berthold's position on the modalities of the soul's knowledge of God, one needs to combine these central passages from Expos. tit. B-D with other texts from the Expositio. Read on their own, these passages in the Expositio tituli, which speak of the Proclus ascending to the knowledge of God "by the guidance of the natural light of the intellect" (ductu luminis naturalis intellectus), and then summarise each motion without implying any order between them, could easily give the impression that all three motions are equally and immediately available to the soul and can be perfectly achieved by a person's natural powers, independently of divine assistance. But this was not Berthold's view, as will become clear when Expos. tit. B-D is supplemented with other passages that either treat the three motions explicitly (131A, 185G-M), which show there is an order among the three motions, or those that discuss the Proclean proof-texts Berthold associated with those motions in greater detail (123D, 202A-F), which show how divine grace is operative in the ordered ascent through the motions. ${ }^{20}$ Since Berthold's aim in the Expositio tituli was to demonstrate that Proclus had in fact exercised all three motions, these nuances were not necessary. But they are required for a full account of his understanding of Platonism. Already before Proclus, according to Berthold, "Plato pursued the cognition of God and the highest craftsman by all of these ways", such that in Proclus we find nothing that is not a restoration of Plato's philosophy to its complete and original form. ${ }^{21}$ As we will see, Berthold's commitment to Dietrich of Freiberg's noetics led him to depart from Thomas of York. In sum, we may say that, according to Berthold, the circular motion belongs approximately to the same level as the direct motion, and each

19 Berthold of Moosburg, Expositio, Expos. tit. A, p. 37, l. 30 - p. 38, l. 34: in hoc apparet excellentia eius, quod per triplicem motum, quos ascribit divinus Dionysius 4 cap. De divinis nominibus $K[\ldots]$ ascendendo pervenit, quantum fuit possibile homini mortali ductu luminis naturalis intellectus, in notitiam summi boni. Cf. 131A, p. 19o, l. 11-13: qualiter sapientes mundi per triplicem motum [...] ascenderunt, ut cognoscerent Deum esse. On Berthold's modifications of Dionysius, see L. Sturlese, "Berthold of Moosburg, the unum animae, and Deification", forthcoming. Later, in Expos. tit. E-F, we find that Berthold even borrowed Thomas' praises of wisdom itself (Sapientiale, lib. I, c. 1 and 3) and applied them directly to Proclus!

20 See also I. Zavattero, "La figura e il pensiero di Proclo in Bertoldo di Moosburg", in ARKETE. Rivista di studifilosofici 1(2005), p. 51-67, at p. 6o, who has rightly emphasised that, in the Expositio tituli, Berthold treats Proclus as a pagan enlightened by grace ("un 'infedele' toccato dalla 'grazia'"). Berthold of Moosburg, Expositio, Expos. tit. D, p. 40, l. 134-135. 
of these higher motions either follows from a special grace or following the perfection of the oblique motion, which makes the mind more receptive to that divine gift.

In the Expositio tituli (unlike the more faithful reproduction of Thomas' doctrine of the three motions we will see in $131 \mathrm{~A}$ ), the circular motion begins not with the senses but by seeking God through introspection and by directly beholding the soul's innate content. Here Berthold cited Proclus on how, quieting its lower activities, the soul beholds "the harmonic reasons" from which it is constituted, the "many lives of which it is the completion", and "recollects that it is itself a rational world" and an image of that from which it has come. Then, returning to its highest intelligence (summa intelligentia), the soul gazes upon its "sister souls" in the world, the intellectual substances above them and, prior to these, the unities of the gods. ${ }^{22}$ According to Berthold, Boethius' definition of intelligentia, which we encountered already in his gloss on Psalm 42, expressed the same doctrine in a summary form: "there exists a higher eye of intelligence, for surpassing the bounds of the universe it views that simple Form by the pure apex of the mind [pura acies mentis]". ${ }^{23}$ The principal distinction here, therefore, is between ratio and intelligentia, the former conceived as proper to the soul, while the latter is the higher mode by which it looks beyond itself to the simple Form flowing through the universe.

In the Expositio tituli, the difference between the circular motion on the one hand, and the direct and oblique on the other, was that the direct and oblique begin from the senses. On this question Berthold followed Thomas closely. ${ }^{24}$ The oblique motion begins from creatures regarded as "vestiges". By a process of laborious inquiry (per laboriosam investigationem), the soul divides, defines, uses common principles, passes from known to unknown, from things sensible to things intelligible, until it comes to the highest Good. This is the

22 Berthold of Moosburg, Expositio, Expos. tit. B, p. 38, l. 49 - p. 39, l. 71, using Proclus, De providentia, c. 6, §18-19. In Thomas' account, followed more closely in 131A, the self-conversion in the circular motion is related to the soul's inherent need for self-sufficiency that it finds only in God.

23 It is not necessary to modify the texts of the Oxford and Vatican manuscripts (intellectivam | intellectivae) after Basel (intelligentiam | intelligentiae). Berthold used both terms synonymously for a mode of knowing beyond intellectus. See Berthold of Moosburg, Expositio, 44C, p. 75, l. 100 - p. 76, l. 116: where intelligentialem is used interchangeably with intelligentialis and intellectivalis (p. 76, l. 112-116). Cf. 185L, p. 27, 1. 436: intelligentiae; 186H, p. 39, l. 312 and p. 40, l. 337: intelligentialis; 202D, p. 186, l. 152: intelligentiam.

24 See also Berthold of Moosburg, Expositio, 131A, p. 191, l. 28-30: Motus autem animi praeter istum circularem est duplex, scilicet obliquus et rectus, quia potest inspicere ipsum creatum bonum tanquam vestigium aut tanquam exemplum. Cf. Thomas of York, Sapientiale, lib. I, c. 6 . 
path of discursive reason (per ratiocinationem). The Elementatio theologica itself, Berthold claimed, is proof that Proclus has ascended by this motion. He then gave Proclean proof-texts for each of the oblique motion's three startingpoints (these starting-points were directly taken from the Sapientiale): Proclus ascended from "the condition of [God's] works", in the first 12 propositions of the Elementatio; from "the governance of what is created", in Proposition 120 and thereafter, as well as in De decem dubitationibus; and from "the reconciliation of contraries", as in Proposition 20 on the four genera (maneries) of being (Nature, Soul, Intellect, One), which are arranged insofar as the divided and lower presupposes the unified and higher, and in De malorum existentia. ${ }^{25}$ The De providentia et fato was not mentioned here because, it seems, at least some of this treatise was more exemplary of the direct and circular motions.

In the Sapientiale, followed closely by Berthold in ${ }_{131} \mathrm{~A}$, Thomas had explained the relation between the oblique and the direct motion as follows. He described how the few pagans (infidelis) capable of completing the oblique motion then commenced the direct motion (motus directus), which he intriguingly identified with a "direct vision of God" (directa visio ipsius). ${ }^{26}$ The direct motion begins also with the senses, but sets out from creatures regarded as "tokens, images, and signs" rather than vestiges, ascending to God "intellectually" rather than "intelligibly", "unitively" rather than "digressively". One could say that the excellence of the direct motion is a function of the lucidity of the contemplator's vision, in which the creature has become semiotically transparent to its divine exemplar. In Berthold's terms, this would be identical to "the perspicacity of the mind" (perspicacitas animi) that the Elementatio theologica aimed to cultivate. ${ }^{27}$

For his Proclean proof-text of the direct motion in the Expositio tituli, Berthold gave Proclus' summary of Platonic dialectic that is above scientific knowledge (scientia). Practicing dialectic, a person skilfully gathers and divides species, and ascends from the many to the One. At the summit of dialectic is the intuition (intellectus, epibole) of simple beings and the primary terms of demonstrations, beyond which, Proclus declared, Aristotle did not ascend. Scientia belongs properly to the soul as discursive and temporal in its activity, while intellectus belongs to it insofar as soul is an image of its prior

25 Berthold of Moosburg, Expositio, Expos. tit. D, p. 40, l. 110 - p. 41, l. 145. Cf. Thomas of York, Sapientiale, lib. I, c. 7. As was his custom, Berthold specified and expanded Thomas' references, this time to Boethius' Consolatio.

26 Berthold of Moosburg, Expositio, 131A, p. 191, l. 28-44; Expos. tit. C-D, p. 39, l. 73 - p. 40, l. 118. See note 29, below.

Berthold of Moosburg, Expositio, Prol.7, p.14, l. 291-292:exercendum est animiperspicacitas. 
principle. Then there is the cognition above intellect, "which the theologians before Plato also divulged, calling it a truly divine madness", and which Proclus identified as the activity of the one of the soul (unum animae). There, the soul "loves to be at peace, enclosing itself from cognitions, having been made silent, and keeping quiet with inward silence". As Berthold showed more extensively in Prol. 17, Dionysius' teaching about the union (unitio) or unity (unitas) above mind, agrees (concordat) with this doctrine. ${ }^{28}$ Therefore, whereas the oblique motion culminates with the knowledge of the highest Good, which is very much distinct from its discursive beginning-points, the direct motion for Berthold seems to be a more rapid progression through the same steps. It is possible that the means and the end in the direct motion are also more intimately related: perhaps the movement is so rapid precisely because the soul is firmly established in this hidden and unitary principle. Berthold's notion of the perspicacitas animi would imply something like this unity of content and method. Certainly, the unitive cognition of the unum animae is integrated into the direct motion in a way it is not present in the oblique.

Both Thomas and Berthold maintained that the direct motion was "given" to the philosophers (paucis datus est infidelibus), who fell into two groups: those who were given it in its fulness by a special grace (per gratiam specialem) and those who received it after perfecting the arduous oblique motion of discursive reason. ${ }^{29}$ How did Berthold understand this in terms

28 Berthold of Moosburg, Expositio, Expos. tit. C, p. 39, l. 73 - p. 40, l. 108.

29 Berthold of Moosburg, Expositio, 131A, p. 191, l. 40-44, citing Sapientiale, lib. I, c. 6 (MS Firenze, Biblioteca Nazionale Centrale, Conv. Soppr. A.vi.437, f. 6vb): Primus istorum duorum motuum [= motus obliquus] fuit in philosophis: Quod enim notum est Dei, manifestum est illis. Secundus autem motus [= motus rectus] paucis datus est infidelibus et, si quibus datus, hoc tenuiter propter hoc, quod iste motus non est datus multis in sua excellentia nisi per gratiam specialem aut non nisi propter praecedentem obliquam animi motionem et hoc perfectam, quod paucissimis datum est. In Sapientiale, lib. I, c. 6, not cited by Berthold, Thomas went on to speak of a lesser "vestige" of the direct motion among those who, "by a simple reflection [simplici speculatione], rise from creatures to the creator through the contemplation of creatures" (Attamen huiusmodi motus, qualecumque vestigium fuit in quibusdam, qui simplici speculatione surrexerunt a creaturis in creatorem per ipsarum creaturarum considerationem). Thomas explained this vestige using passages from Cicero (De natura deorum II.37) transmitting the parable from Aristotle's De philosophia about the inhabitants of an ornate cave, who know of the gods only by report (fama). Suddenly, an earthquake splits its entrance, and they gaze upon an immense world of beauty, order, and power. Without any disputation (remota omni disputandifacultate) or discursive reasoning they recognize the existence of an intelligence that has made all things. Perhaps Thomas referred to this as a "vestige" of the direct motion as a way of separating this momentary intuition (simplex speculatio) from the more perfect exercise of the direct motion that is enabled either by a special grace (we might think of St. Paul) or after a habitus has been gained by laborious investigation. 
of his own doctrine of the perfection of the oblique motion and the beginning of the direct motion? A glance at $131 \mathrm{~A}$ has clarified that Berthold, like Thomas, maintained that the three motions fell into a certain order, despite the impression given by Expos. tit. B-D. The status of the circular motion, however, will require further explanation. To determine their precise order for Berthold, we must look to Berthold's reception of Dietrich of Freiberg's notion of the acquired intellect (intellectus adeptus). Dietrich's intellectus adeptus differed in several respects from Albert's, not least by placing the emphasis squarely on the necessity of grace for its attainment, for deferring its realisation until the beatific vision, and for describing its temporary enjoyment as a rapture (raptus). Berthold will incorporate Dietrich's intellectus adeptus into the Expositio relative to the culmination of the oblique motion and to the exercise of the circular and direct motions. However, as was noted already, Berthold's notion of the unum animae will also retain some features of Albert's higher stage of the intellectus assimilativus that cannot be derived from Dietrich's writings.

The central passage for this synthesis is $123 \mathrm{D}$, where Berthold produced the most extensively glossed and schematised version of the proof-text (De providentia et fato 8.28-31) for Proclus' exercise of the direct motion used in Expos. tit. C. ${ }^{30}$ Berthold arranged the modes of cognition presented by Proclus into five levels, and subdivided most of them into higher, lower, and medial operations. First and lowest is the exterior sense, whose objects are the extrinsic qualities of beings immediately present to it. The second, called the interior sense or imaginative power, is more intrinsic and spiritual because its objects are quantities and common sensibles that can be apprehended in the absence of the being in which they inhere. The third mode is the discursive or "particular" reason (ratio particularis). Its lowest function is related to the imagination and to the unstable objects of the physical world: through many "probable reasons" this lower function gives rise to "belief" and thus becomes opinion. In the superior function of the particular reason, when it is conjoined with the universal reason (ratio universalis), it is "scientific", and applies itself to pure mathematicals. These provide the stability required for necessary knowledge. These stable principles are used by the particular reason in its medial operation, where it deals with mathematical objects applied to the physical world (res mathematicas applicatas ad physicum), for instance in the quadrivial arts and in sciences like optics. All of this recalls Berthold's adaptation of Albert's Metaphysica in the Prologus on the twofold inquiry (duplex indagatio) 
that human reason has brought to perfection before it begins the study of metaphysics.

The fourth mode of cognition is exercised by the ratio universalis, which constitutes the quidditative being of a thing by apprehending its essential parts in definitional knowledge. ${ }^{31}$ This was effectively Dietrich of Freiberg's notion of the intellectus possibilis. Berthold elaborated this theory by giving the possible intellect three hierarchically ordered operations. ${ }^{32}$ Its lower function, which is related to the particular reason, deals with "logical intentions", which are presumably second intentions like "genus", "species", and so on. With its medial function it is occupied with "metaphysical intentions", which can perhaps be identified with extra-mental intentions like "human" or "horse". In the context of Berthold's citation of Proclus' De providentia et fato, these two operations of Dietrich's ratio universalis were associated with the composing and dividing activities of dialectic, and with the apprehension of the relationship of the principles of the quadrivial sciences to one another until it arrives to the unhypothetical first principle. ${ }^{33}$ Finally, the higher operation of the universal reason no longer proceeds by analyses, divisions, demonstrations, but as "the intelligence of simple beings" it contemplates simple beings by simple intuitions (epybolis simplicibus) and with immediate visions (antopticis). ${ }^{34}$ In Berthold's synthesis, the science of metaphysics as Aristotle pursued it was thus confined to the level of the possible intellect - the consequences of this will be felt when we consider his criticism of the doctrine of the transcendentals in Chapter 4, below.

Finally, with the fifth mode of cognition we have the first mention of the agent intellect and the culmination of the entire ascent, as far as human cognition is concerned:

31 Berthold of Moosburg, Expositio, 123D, p. 129, l. 129-131; Praeamb. C, p. 64, l. 389-39o: rationi universali, quam intellectum possibilem vocamus.

32 Dietrich spoke of the cooperation of the particular and the universal reason in the formation of demonstrations. See Dietrich of Freiberg, De intellectu et intelligibili, ed. B. Mojsisch, Opera omnia, vol. ı. Schriften zur Intellekttheorie (Hamburg: Meiner, 1977), lib. III.27.1 - III.28.1, p. 200, 1. 24 - p. 201, l. 59.

33 Berthold of Moosburg, Expositio, 123D, p. 129, l. 133-134: Quoad ista duo ascendit ad unum primum principium et usque ad insuppositum.

34 Berthold of Moosburg, Expositio, 123D, p. 129, 1. 144-147: Quoad sui autem superius non adhuc utimur methodibus et resolutionibus aut compositionibus aut divisionibus aut demonstrationibus, sed epybolis, id est adiectionibus, simplicibus et velut antopticis, id est per se visivis, entia speculantem, et vocatur simplicium intelligentia, quae etiam in nobis est melior omni scientia. 
The fifth level is the agent intellect, having become the form of this universal reason according to its higher part. This is called the acquired intellect [intellectus adeptus] and 'the one' of this part of our intellectual power, 'no longer operating intellectually and joined to the One. For all things are known by like: the sensible by sense, scientific objects by science, the intelligibles by intellect, and the One by the unifical'. This is 'the most divine cognition of God, which is known through ignorance according to the cognition above mind, when the mind, having departed from everything else, and then also sending itself away, is united with the super-resplendent rays, and is illuminated hither and yon by the inscrutable depth of wisdom. ${ }^{35}$

Berthold's apparently straightforward identification here of the acquired intellect and unum animae is singular in the Expositio, and has led to some divergent recent interpretations of his thought on this important issue. In an earlier study, I made this passage from $123 \mathrm{D}$ central to an interpretation of Berthold's thought that placed him fundamentally in continuity with Dietrich of Freiberg's theory of the soul's return to and intellectual union with God. The similarities between Dietrich's intellectus adeptus and Berthold's unum animae, and their agreement that a rapture is required for wayfarer to enjoy this highest form of cognition, seemed so strong that the the divergence between the two authors was reduced there to a merely verbal difference: for Berthold, once a person has the acquired intellect, the cognition of the unum animae follows spontaneously. ${ }^{36}$ In a more extensive consideration of this question in Berthold, Paul Hellmeier has argued that this apparent identification of the intellectus adeptus and unum in ${ }_{123} \mathrm{D}$ should in fact be understood merely as a mistake on Berthold's part. For Hellmeier, ${ }_{123} \mathrm{D}$ is inconsistent with the clear

35 Berthold of Moosburg, Expositio, 123D, p. 129, l. 148-155: Quintus gradus est intellectus agens factus forma praedictae rationis universalis secundum sui ipsius rationis superius, et vocatur intellectus adeptus et 'unum' ipsius partis nostrae intellectualis, 'non adhuc intellectuale excitantem et hoc coaptantem uni. Omnia enim simili cognoscuntur: sensibile sensu, intelligibile intellectu, unum uniali'. Haec est 'divinissima Dei cognitio, quae est per ignorantiam cognita secundum cognitionem super mentem, quando mens ab aliis omnibus recedens, postea et se ipsam dimittens unita est supersplendentibus radiis divinorum, inde et ibi non scrutabili profundo sapientiae illuminata'. Cf. Proclus, De providentia et fato, c. 8, §31, p. 140, 1. 6-9, and Dionysius, De divinis nominibus, 7.3, 872A-B.

36 E. King, "Berthold of Moosburg on Intellect and the One of the Soul", in Dionysius 36(2018), p. 184-199. 
subordination of intellect to the unum animae outlined in several other passages in the Expositio. ${ }^{37}$

I would now maintain that the truth is somewhere in the middle of these interpretations. I continue to hold that $123 \mathrm{D}$ is crucial for understanding Berthold's intentions, not least because I do not believe that Berthold would make a mistake in the most elaborate discussion of the modes of cognition in the Expositio. Hellmeier is right to propose that there is a clear and consistent subordination of intellect to the unum animae in Berthold. But the ambiguity in ${ }_{123} \mathrm{D}$ can be explained in another way without dismissing it as an error. If there is any problem with ${ }_{123} \mathrm{D}$, it was rather that Berthold was not being precise enough.

Berthold was consistent in maintaining that the intellectus adeptus and unum animae belong to the same mode or level of cognition - the attainment of the latter follows on the former. However, what Berthold did not make sufficiently clear was that he continued to apply a pattern of higher and lower subdivisions within this fifth mode. In other words, the acquired intellect should be understood as the lower phase and the unum animae the upper phase of the same level (intelligentia). Perhaps he did not separate them into distinct "operations" because, strictly speaking, one cannot exercise the unum animae independently of the intellectus adeptus and, again, as soon as the acquired intellect is reached, it passes spontaneously into the unum animae. If we entertain the possibility that the acquired intellect and the unum are related in this way, we can see that Berthold has not only synthesised the Albertine distinction of acquired and assimilated intellects with the theory of the acquired intellect derived fundamentally from Dietrich of Freiberg: as we shall see, by rendering the difference between Dietrich's adeptus and Albert's assimilativus in the language of Dionysius and Proclus, Berthold has produced a doctrine that in fact closely resembled a position on the nature of beatitude taken by Meister Eckhart.

The relationship between the agent intellect and the unum animae is sometimes presented very ambiguously in the Expositio. In two passages discussing the soul's most intrinsic and essential principle, which were inspired by Dietrich, ${ }^{38}$ one has the impression that for Berthold the unum animae was nothing else than the facies of Augustine or the intellectus agens of Aristotle:

37 P. Hellmeier, "Der Intellekt ist nicht genug. Das proklische unum in nobis bei Berthold von Moosburg”, in Philosophisches Jahrbuch 126/2(2019), p. 202-226, at p. 219-221. Hellmeier very insightfully emphasises the influence of Albert on Berthold's theory, although I do not share the opinion that Albert was more important than Dietrich for Berthold's synthesis.

Dietrich of Freiberg, De intellectu et intelligibili, II.2.1 - II.12.1, p. 147, l. 50 - p. 155, l. 81. 
The rational soul not only lives animately, but also intellectually, and consequently has in itself the principle of its motion, namely 'the one of the soul itself', which some call 'the deiform unity', others 'the hidden recess of the mind' or 'face', but others call it 'the agent intellect'. ${ }^{9}$

However, this intellective power is the higher, essential part of the soul, which Aristotle calls 'the agent intellect', Augustine 'the hidden recess of the mind', and Dionysius 'the union' or 'the unity' (as the other translation says) 'exceeding the nature of the mind' [...] but the author calls it 'the one of the soul'. 40

Like ${ }_{123} \mathrm{D}$, these passages show that Berthold did not want to posit a sharp divide between the agent intellect and the unum animae. Nevertheless, given his commitment to the subordination of Aristotle to Plato on this central question of anthropology, it is difficult to imagine that he would not want to establish some difference between the two, and this makes his apparent equivocations here rather perplexing. In isolation, these passages give us very little explanation. Fortunately, the ambiguity can be resolved by context. In both cases, Berthold was discussing the immediate and essential principle of the soul, and so we must be sensitive to the fact that, according to the law of mediation, the intellect and not the unum animae would be the proximate principle of its essence. ${ }^{41}$ By including the Proclean and Dionysian unum alongside the intellectus agens Berthold was in fact consistent in his view that for the Platonists the more universal cause is more active than the secondary cause. Although the two principles are placed at the same level, for Berthold the agent intellect is the immediate and essential principle of the soul only in virtue of the more causally efficacious unum animae. ${ }^{42}$

Berthold's lemmatic commentary in the Prologus on the phrase "light of the simple intellect" (lumen simplicis intellectus), from the Hermetic description

39 Berthold of Moosburg, Expositio, 188E, p. 65, l. 204-207: quae non solum vivit animealiter, sed etiam intellectualiter, et per consequens habet in se principium sui motus, scilicet 'unum ipsius animae', quod quidem vocant 'deiformem unitatem, alii vero 'abditum mentis' sive 'faciem', quidem autem 'intellectum agentem'.

Berthold of Moosburg, Expositio, 193E, p. 103, l. 123 - p. 104, l. 134: tale autem intellectivum existens pars animae essentialis superior, quod Aristoteles vocat 'intellectum agentem, Augustinus 'abditum mentis', Dionysius vero 'unitionem' sive 'unitatem' (ut dicit alia translatio) 'excedentem mentis naturam, [...] sed auctor vocat 'unum animae'.

41 Cf. Berthold of Moosburg, Expositio, 68E, p. 17, 1. 93-95: Similiter intellectus agens cum uno sui, qui etiam est totum in parte et pars totius potestativi ex partibus, quod est anima, continet in se virtute totam residuam substantiam animae, in qua convenit cum corde. Berthold of Moosburg, Expositio, 24B, p. 130, l. 189-198; 162B, p. 17, l. 51- p. 18, l. 6 o. 
of the microcosm, presented the same doctrine. ${ }^{43}$ Berthold had just explained how the human receives "through the imago Dei" the "beauties not immersed in the world", which are the three levels of gods or separate substances (according to cause: God; according to essence: the gods; according to participation: their orders).${ }^{44}$ There is, he noted, a twofold similarity in the imago. In one respect, the human is an image of the primordial cause of intellect (prime intellectus) and is similar to intelligible beauties, and thus it is called "the simple intellect". As an image of the One, however, the human resembles the first principle and the primordial causes themselves, and as such the imago is the unum animae or "the light of the simple intellect".

Through the unum animae, the mind enters the supersubstantial world where, as Dionysius wrote, "the simple, absolute, and unchanging theological mysteries lie hidden away in the super-resplendent darkness of the silence teaching hiddenly, the darkness [...] that fills to excess with beyond-beautiful lucidities minds that are dispossessed of eyes [non habentes oculos mentes]". 45 Berthold's comments on this passage specified that the oculus mentalis is the agent or the simple intellect, "which is also light, as Aristotle says". But the unum is more luciform (luciformius) than the simple intellect and, therefore, is more truly the imago Dei. However, following the semantic register of Psalm 4:7 (Signatum est super nos lumen vultus tui, Domine), Berthold's vocabulary immediately became Augustinian, when he added that the unum animae can be identified with the soul's face (facies sive vultus), the hidden depth of the mind (abditum mentis), and the superior reason (ratio superior) that is always turned to the divine light. As with $123 \mathrm{D}, 188 \mathrm{E}$, and ${ }_{193} \mathrm{E}$, we find that the agent intellect and the unum animae are brought closely together, though Berthold nevertheless maintained a decisive but subtle distinction between them: the agent intellect must be acquired and then "dispossessed".

A similar distinction can be found in Propositions 185 and 202, which contain Berthold's analyses of the same Dionysian and Proclean texts used already to describe the three motions of the soul. These passages are the most illustrative of the doctrine of the intellectus adeptus that was presupposed in $123 \mathrm{D}$. In Propositions 185 and 202, William of Moerbeke's intriguing translation of $\psi v \times \alpha i$ o $\pi \alpha \delta \delta i$ ( the souls participating intellect who are always "attendant" upon

43 Berthold of Moosburg, Expositio, Prol. 19, p. 3o, l. 838 - p. 32, l. 878.

44 Berthold of Moosburg, Expositio, Prol. 18-19, p. 27, l. 729 - p. 30, 1. 837. The phrasing at Prol. 17, p. 26, l. 691-693, indicates that Dietrich's theory of the agent intellect as the imago Dei was a primary inspiration for this portion of the Prologus.

45 Berthold of Moosburg, Expositio, Prol. 19, p. 31, 1. 851-857. Cf. Dionysius, De mystica theologia, 1.1, 997A-B. 
the gods) as animae contemplatrices provoked Berthold to set out a theory of contemplation. ${ }^{46}$ At the basis of this theory was Dietrich's doctrine of the acquired intellect, which Berthold adjusted to fit the demands of Proclus' distinction between the perpetual "attendance" or contemplation of divine and intellectual souls and the episodic "attendance" of human souls.

In the De visione beatifica, Dietrich had addressed certain arguments of "the philosophers", whose views on the relation of the agent and possible intellects seemed to resemble his own. He stated that they raised "the same, or at least a similar, question" as he had regarding the possibility of intellectual beatitude, although their answers will differ in a crucial respect. ${ }^{47}$ The philosophers maintain that the agent intellect is sometimes (aliquando) united to the possible intellect or the essence of the soul as a formal cause in this life (in hac vita), since the agent intellect is both the primary efficient cause of cognition, making the possible intellect to know in act, and is the form or light of the possible intellect's intelligible objects, which are the secondary cause of its knowing. ${ }^{48}$ Dietrich then summarised the philosophers' views about the determinate ratio that descends from the agent intellect and provides the possible intellect with its content. It is the principle by which the possible intellect is actualised and constitutes its quidditative knowledge of a thing. These rationes flow immediately from the eternal reasons in God into the agent intellect, where they are in some way determined or limited, and thence proceed into the possible intellect. According to Dietrich, the philosophers' position, if left here, would have the unacceptable consequence of making God the formal cause of every act of intellection. ${ }^{49}$ Dietrich responded to this by underscoring the difference between thinking a thing by its ratio and thinking it essentially (per essentiam). Only the latter cognition, which belongs to the agent intellect, is a "likeness of the universe of being" and embraces all things in its essential activity. Therefore, the possible intellect does not enjoy the beatific vision whenever it knows any determinate ratio - it does not know God directly - but only when it receives a ratio that amplifies the scope of its cognition to this universal or "essential" extent, that makes it adequate to the cognition of the

46 In Proclus, De decem dubitationibus circa providentiam, q. 10, §65, cited at Berthold of Moosburg, Expositio, 134F, p. 218, l. 140, William transliterated the term and offered a more prosaic translation: opadoy, id est assequentes.

47 Dietrich of Freiberg, De visione beatifica, 4.2 .1 (1), p. 106, 1. 40-43.

48 Dietrich of Freiberg, De visione beatifica, 4.2 .1 (2-7), p. 106, l. 44 - p. 107, l. 83. Dietrich shared the view he attributed to Alexander of Aphrodisias, Al-Farabi, and Averroes that the actualised possible intellect is identical to the intelligible species.

Dietrich of Freiberg, De visione beatifica, 4.2.1 (8-10), p. 108, l. 84-111. 
agent intellect. Now, the possible intellect always uses a ratio to express the formal parts of a thing, which are the principles of a thing's being and its beingknown. Since the human intellect always knows by these determinate rationes, it is incapable of knowing the simpler quiddities of the separate intellects, "if they exist". ${ }^{0}$ All the more, then, must the possibility of beatitude through the intellectus adeptus, when the possible intellect will be united to the agent intellect by the amplitude of such a ratio, be understood as a Scriptural promise and not a natural fact. ${ }^{51}$

For Dietrich, therefore, the acquired intellect is attained only in heaven (in patria), when the blessed think by the divine mode of cognition that is perpetually active in the individuated agent intellects that are the grounding principles of their souls. ${ }^{52}$ Importantly for Berthold, Dietrich also acknowledged the possibility of a transitory enjoyment of this cognition, giving the example of St. Benedict who, according to Gregory the Great (Dialogues II.35) "saw the whole universe in a certain elevation of the mind" or rapture. ${ }^{53}$ Dietrich likely found in this report a verification of his view that the ratio that beatifies the intellect comes directly from God and includes in its simplicity the ambit of the entire universe. It elevates or expands the possible intellect to the essential cognition of the agent intellect. But it is also clear from his passing reference to Benedict's vision (sed qualiter hoc contigerit, Deo committendum iudico), that this kind of transitory experience was not his primary concern in the De visione beatifica. Dietrich was more interested in articulating the necessary conditions of intellectual activity and beatitude than in verifying its exceptional historical realisations.

$5^{\circ} \quad$ Dietrich of Freiberg, De visione beatifica, 4.2.1 (13-14), p. 109, l. 131-145.

51 Dietrich of Freiberg, De visione beatifica, 4.3 (1), p. 111, 1. 29-31: Aliter igitur procedendum ad propositum supposito hoc, quod per scripturam veritatis nobis promittitur, eo, quod per rationem solam hoc concludi non potest, videlicet quod in beata vita visuri simus Deum in claritate suae essentiae.

52 Dietrich of Freiberg, De visione beatifica, 4.2.1 (4), p. 107, 1. 56-59: Ex hoc enim nunc secundum statum huius vitae non intelligimus ea intellectione, qua ipse intelligit, quia secundum hunc statum non est nobis unitus ut forma, sed solum ut principium intellectorum in nobis.

53 Dietrich of Freiberg, De visione beatifica, 1.1.4 (5), p. 29, 1. 27-33: Et ex hoc arguit Commentator Super III De anima, quod, si intellectus agens, qui est intellectus per essentiam et semper in actu, aliquando uniatur nobis ut forma, per ipsum intelligemus omnia entia. Quod videtur aliqualiter concordare cum eo, quod legitur de sancto Benedicto, videlicet quod in quadam mentis elevatione vidit totum universum. Sed qualiter hoc contigerit, Deo committendum iudico. On the interpretation of Benedict's vision in medieval thought and art, see M. Kupfer, "The Cosmic Vision of Saint Benedict, e specula and in speculo", in N. Bouloux, A. Dan, G. Tolias (eds), Orbis disciplinae. Hommages en l'honneur de Patrick Gautier Dalché (Turnhout: Brepols, 2017), p. 139-165. 
Berthold understood the details of Dietrich's theory very well, and repeated his view that the acquired intellect is not a natural fact but must fall within the order of voluntary providence, "the completion and consummation of natural providence", for it pertains "only to God's grace and good merits". ${ }^{4}$ This concluding passage from his commentary Proposition 202 most fully displays his agreement with Dietrich on this matter:

Now, although intellectual souls are below divine souls, yet they are expanded above partial [=human] souls. For these, although they participate intellect by intellectual activity, are unable to participate [their] proximate intellect or intellectual essence, the acquisition of which [cuius adeptione], such that it would be their form, they lack as long as they are in becoming; otherwise, they would not have inclined away from intellectual activity. For what acts essentially acts always, and souls who have acquired their essential intellect [animae intellectum essentialem adeptae] do exactly this. For this reason, [human souls] are more fittingly called "rational" than "intellectual". However, by a gift of God, at some moment [aliquando] even in this mortal life, they are elevated not only by their intellectual power, but even by their unifical power or one [suo uniali seu uno] to the height of contemplation, to a vision, not only of the gods, whom God has established as his dwelling-place, but even of him, the Lord God almighty and the great King above all gods.

But after this life, meritorious and well-pleasing souls by the grace of God (that is, by the light of glory), will have their own intellects formally united to themselves, and thus their blessed vision will be fulfilled insofar as they shall see God, Lord of gods, face to face - [having become] mirrors throughout all eternity. But intellectual souls do not lack this; indeed, they always have it by a gift of the primarily God. ${ }^{55}$

54 Berthold of Moosburg, Expositio, 129F, p. 182, l. 288-302. Cf. Dietrich of Freiberg, De visione beatifica, 4.3.2 (2-4), p. 114, 1. 3-20.

55 Berthold of Moosburg, Expositio, 202F, p. 187, l. 217 - p. 188, l. 233: Verum licet [animae intellectuales] sint inferiores divinis animabus, tamen superexpansae sunt partialibus, quae, licet participent intellectu per intellectualem operationem, non potentes intellectu proxime participare seu intellectuali essentia, cuius adeptione ita, quod sit eis forma, carent, quamdiu sunt in generatione, quia alias non deciderent ab intellectuali operatione operans enim per essentiam semper operatur, sicut faciunt animae intellectum essentialem adeptae, propter quod et magis vocantur rationales quam intellectuales -, tamen dono Dei aliquando etiam in hac mortali vita, non iam suo intellectuali, sed etiam suo uniali seu uno altitudine contemplationis elevantur in visionem non solum deorum, quos posuit prime Deus suum latibulum, sed etiam eius, qui est Deus magnus dominus et rex magnus super omnes deos. Sed post hanc vitam bene meritae animae Dei gratia (scilicet lumine 
While the relation of the intellectus adeptus and grace described here is perfectly consistent with Dietrich's teaching, Berthold has made the relation less hypothetical by transposing it into the cosmological framework of the Elementatio. For Berthold, heavenly or "intellectual" souls must already enjoy the same cognition that will belong to the blessed in patria. At the same time, and even more forcefully than Dietrich, Berthold emphasised the necessity of grace for the acquired intellect, and even reintroduced the notion of "the light of glory" (lumen gloriae) that had been explicitly rejected by Dietrich. ${ }^{56}$ However, one should not rush to characterise this as a misreading of or radical departure from Dietrich; it was rather an attempt to reintroduce the lumen gloriae after Dietrich's criticisms. The intelligible species or ratio descending from God in which (rather than under which) the possible intellect knows the divine essence in its amplitude could easily be regarded as a gift enabling it to approximate the intrinsic vision of God that belongs inherently to the agent intellect as an intellectus in actu per essentiam. In this sense, Berthold would be attempting to safeguard Dietrich's theory from naturalistic misinterpretations by putting the emphasis squarely on the necessity of grace.

Berthold's reception of Dietrich on this score can be compared with the nearly identical conclusions drawn in the vernacular treatise Ler von der selikeyt (The Doctrine of Beatitude), written sometime between 1302 and $1323 .{ }^{57}$

gloriae) habebunt sibi proprios intellectus formaliter unitos, et sic complebitur eorum visio beata, inquantum videbunt Deum deorum dominum facie ad faciem specula in aeterna. Tali autem unione non carent intellectuales animae, verum semper habent eam dono prime Dei. There are three options for interpreting the phrase specula in aeterna: (1) specula, the nominative plural of speculum, is in apposition to animae (as translated above); (2) specula is the ablative singular of "watchtower" ("from a watchtower"); (3) as a poetic word order, in specula aeterna ("in eternal mirrors"). In aeterna itself could signify either a temporal designation ("through all eternity") or, less likely, a multiplicity of objects seen (looking "in things eternal"). The sense of the passage is clearly that the beatific vision presupposes the intellectus adeptus, when the agent intellect, which could be described as a "mirror" of God's light in the rest of the soul, is now united with the soul in a new way (as thoroughly as form is united to matter). Since blessed souls could therefore be called "mirrors", I have translated following the first option. If this was Berthold's intent, he was likely evoking 2 Cor. 3:18 (Nos vero omnes, revelata facie gloriam Domini speculantes, in eamdem imaginem transformamur a claritate in claritatem, tamquam a Domini Spiritu) in addition to 1 Cor. 13:12 (facie ad faciem). It cannot be excluded that Berthold was also alluding to the Boethian notion of "the watchtower of providence", given that the intellectus adeptus is so closely related in the Expositio to cognitio providentialis. See Conclusion, section 2, n. 96. For his patient discussion of this passage with me, I am very grateful to Paul Hellmeier OP.

$5^{6}$ Dietrich of Freiberg, De visione beatifica, 3.2.3, p. 72, 1. 39 - p. 73, 1. 79.

57 The text is edited with a commentary in N. Winkler, Von der wirkenden und möglichen Vernunft. Philosophie in der volkssprachigen Predigt nach Meister Eckhart (Berlin: De 
This treatise addressed the question of the primacy of the agent or possible intellect in the beatific vision. Its author advocated Dietrich's views above those of Thomas Aquinas and even above the doctrine of emptiness or passivity ascribed to Meister Eckhart (daz saelicheit lige an got lîden). The text also went beyond anything we find in Dietrich to explore some of the ethical consequences of his noetics.

The anonymous author's central argument was that an intellectual substance like the agent intellect cannot be deprived of its natural operation. Following Dietrich's arguments about the agent intellect as an imago Dei that is always actually thinking God, itself, and the universe of beings, the author goes further than any declaration we have in Dietrich to state that the imago or scintilla animae is "blessed by nature" (saelec sî von nâtûren). ${ }^{58}$ Such expressions come rather close to the fifth thesis attributed to the beguines and beghards censured at the Council of Vienne in 1311-1312: "that any intellectual nature in itself is naturally blessed, and that the soul does not need the light of glory to elevate it to see God and enjoy him blissfully". ${ }^{59}$ For the anonymous author, however, this theory of natural beatitude was not inconsistent with the tenet that the possible intellect still requires divine grace in order to be transformed by the agent intellect. ${ }^{60}$ Nevertheless, his position about the natural beatitude of the agent intellect led the author to develop certain original ethical theories, including a presentist understanding of hell as each mortal sin, which thereby becomes an "eternal middle" standing between the soul and the enjoyment of this immediate vision of God already underway but "hidden" in the

Gruyter, 2013). See also Sturlese, "Alle origini della mistica speculativa tedesca", p. 48-87; id., “Traktat von der Seligkeit”, in K. Ruh et al. (eds), Die deutsche Literatur des Mittelalters. Verfasserlexikon, vol. 9 (Berlin: De Gruyter, 1995), p. 998-1002; N. Largier, "Das Glück des Menschen. Diskussionen über beatitudo und Vernunft in volkssprachlichen Texten des 14. Jahrhunderts", in J. Aertsen, K. Emery, Jr., A. Speer (eds), Nach der Verurteilung von 1277. Philosophie und Theologie an der Universität von Paris im letzten Viertel des 13.Jahrhunderts (Berlin: De Gruyter, 2001), p. 827-855; A. Beccarisi, "Dietrich in the Netherlands. A New Document in the Lower Rhenish Vernacular", in J. Biard, D. Calma, R. Imbach (eds), Recherches sur Dietrich de Freiberg (Turnhout: Brepols, 2009), p. 221-237; Saccon, Intelletto e beatitudine, p. 161-173.

58 Lervon der selikeyt, ed. N. Winkler, p. 42, l. 16 - p. 43, l. 2; p. 44, l. 9; and p. 45, l. 14.

59 Constitution Ad nostrum qui, in H. Denzinger, Enchiridion Symbolorum, ed. P. Hünermann (Freiberg / Basel / Wien: Herder, 2009 ${ }^{46}$ ), §895: Quinto quod quaelibet intellectualis natura in se ipsa naturaliter est beata quod que anima non indiget lumine gloriae ipsam elevante ad deum videndum et eo beate fruendum. See also R. Lerner, The Heresy of the Free Spirit in the Later Middle Ages (Berkeley: University of California Press, 1972), p. 61-84.

Lervon der selikeyt, p. 41, l. 18 - p. 42, l. 7 . 
intellect. ${ }^{61}$ Although the anonymous author explicitly ascribed his doctrine of the natural beatitude of the imago Dei to Dietrich, ${ }^{62}$ it is important to bear in mind that he has made no recourse to the distinction of the orders of natural and voluntary providence, of nature and grace, that Dietrich was so careful to observe. ${ }^{63}$ All the same, here and in the position censured by the Council of Vienne, one may discern the explosive potential in Dietrich's theory for a reform of Christian self-understanding through a philosophical account of the dignity of the intellectual creature. This potential was creatively harnessed by the anonymous author and, more carefully, by Berthold of Moosburg and John Tauler. For Dietrich, Berthold, and Tauler, this path of "natural beatitude" was definitively the road not taken. For Dietrich and for Berthold, beatitude for human beings is only beatitude when it is communicated to the entire person; it makes no sense to say a "part" of the soul is always blessed because it always gazes upon God or the divine ideas. What matters is how this cognition can be participated by the entire soul, and this necessarily depends on grace. The Ler von der selikeyt did not observe this intrinsic connection between beatitude and grace.

Berthold's integration of Dietrich's theory into a Proclean and Dionysian framework intensified both sides of this relationship, that is, the actuality of beatitude as well as the need for divine grace. Like the Ler, Berthold placed greater emphasis than Dietrich on the possibility of the soul's foretaste of beatitude in this life, rather than deferring it to the eschatological future. His doctrine of contemplation in Propositions 185 and 202 consistently maintained that a transitory enjoyment of divine union is in fact granted by a gift of God sometimes (aliquando) to human souls and always (incessanter) to heavenly souls. Berthold's focalisation of Thomas of York's interpretation Dionysius' three motions on the historical figure of Proclus demanded that it be so. In

61 Ler von der selikeyt, p. 44, l. 19 - p. 45, l. 11. These coincide with the author's use of an Eckhartian motif: to dispose oneself to receive divine grace, one's possible intellect must rid itself of all images. See Ler von der selikeyt, p. 45, l. 15 - p. 46, l. 7 .

62 Lervon der selikeyt, p. 41, l. 8-11; p. 42, l. 8-15.

63 Sturlese, "Alle origini della mistica speculativa tedesca", p. 64-68. In his history of debates on the beatific vision, Christian Trottmann correctly emphasised the importance of Dietrich's view about the intelligible species, derived from his reading of Alexander, Al-Farabi, and Averroes, for his rejection of the Thomistic lumen gloriae. However, his conclusion (La vision béatifique. Des disputes scholastiques à sa définition par Benoît XII [Paris: École française de Rome, 1995], p. 335) that "la thèse de Dietrich de Freiberg ne permet pas de penser la caractère surnaturel de la vision béatifique puisqu'elle ne procède pas d'une grâce" is an even less balanced account of Dietrich's own theory than what we have in the Lervon der selikeyt. 
turn, the text of the Elementatio shaped the doctrine Berthold presented: contemplation must be an activity exercised equally by human and heavenly souls. With this came a stronger focus on the circular motion, which Berthold to be the contemplation characteristic of heavenly souls, than anything in Thomas of York. ${ }^{64}$ Here we see once again how closely Berthold associated the highest level of intellect and the unum animae: in Proposition 185, he applied Dionysius' words ("it is granted [conceditur] to few souls to be admitted [admittantur] to such heights of contemplation") relative both to the intelligentia at the summit of the circular motion, ${ }^{65}$ and to the union or unity above mind. ${ }^{66}$ In Proposition 202, Berthold classified a series of passages from Bernard of Clairvaux, Richard of St. Victor, Dionysius, and Proclus, according to whether they pertain to contemplation in this life (in via), in heaven (in patria), or to both. As with Proposition 185, he made it clear that the difference between contemplation in via and in patria concerns not the quality but the stability of contemplation, when the aliquando changes to incessanter. ${ }^{67}$ Even now, that is, the souls moving the heavens exercise steadfastly and unswervingly (firme et indeclinabiliter) the highest intelligence (intelligentia), which Berthold described with the same text used for the circular motion in Expos. tit. B, in which the soul looked within itself and above itself, to its "sister souls", the intelligences, and the divine unities. This in turn gives way to the cognition above mind of the unum animae that is the basis for their providential cooperation with God. ${ }^{68}$ Thus, for Berthold, there is a certain beatitude in nature, but it belongs to these heavenly "contemplative" souls, which are already in patria through a divine gift.

In all these passages - the proximate essential cause of the soul $(188 \mathrm{E}$, ${ }_{193} \mathrm{E}$ ), the two dimensions of the imago Dei (Prol. 19), the modes of cognition $(123 \mathrm{D})$, the kinds of contemplation $(185 \mathrm{G}-\mathrm{M}, 2 \mathrm{O} 2 \mathrm{~A}-\mathrm{F})$, and also the figure of the

64 For intelligentia of the circular motion as the highest kind of cognition, see also Berthold of Moosburg, Expositio, 44C, p. 75, l. $100-$ p. 76, 1. 120 (operatio intelligentialis is above, supra, the operatio intellectualis); 63C, p. 188, 1. 62-66; 185L, p. 26, 1. $412-$ p. 28 , 1. 455 (intelligentia as the highest mode of cognition).

65 Berthold of Moosburg, Expositio, 185M, p. 28, 1. 457-471: quia anima non semper movetur motu circulari, ut fiat informis uniens se unitis virtutibus, nec semper est statuta se tota extra se totam et supra se totam in unitionem excedentis mentis, per quam coniungitur diis per recursum sui ad summam intelligentiam, [...] ideo non semper contemplatur deos, licet aliquando. Quod tamen paucis conceditur animabus, ut ad tantam contemplationis eminentiam admittantur, iuxta illud, quod dicit Dionysius.

66 Berthold of Moosburg, Expositio, 185I, p. 25, l. 369-379.

67 Berthold of Moosburg, Expositio, 202C, p. 185, l. 147 - p. 186, l. 172.

68 Berthold of Moosburg, Expositio, 202B, p. 184, l. 105-111. 
astronomer (Prol. 16) - have shown how closely Berthold associated the agent intellect, or its state of formal union with the possible intellect, and the unum animae. The comparison of the model of the three motions of the soul in Expos. tit. B-D and 131A with Berthold's analysis of their Proclean proof-texts in 123D, $185 \mathrm{G}-\mathrm{M}$, and $202 \mathrm{~A}-\mathrm{F}$ lead us to conclude that Berthold remained fundamentally in agreement Dietrich in his understanding of the conditions of possibility for this beatifying cognition to occur. However, he accentuated Dietrich's marginal reference of Benedict's rapture because of the need to account for the historical attainment of this cognition in its perfection in Proclus himself and, consequently, following the letter of the Elementatio, in heavenly or "contemplative" souls. Berthold's modifications of Albert the Great's De intellectu et intelligibili in Prol. 16 must, therefore, be interpreted in this light, so that the state of the intellectus adeptus, the summit of self-knowledge and the capacity for a kind of natural prophecy, would itself be understood as a transitory state. ${ }^{69}$ If Berthold also intended to replace Albert's intellectus assimilativus with the unum animae, then this too should be interpreted through the lens of $123 \mathrm{D}$ and Berthold's adaptation of Dietrich: once the soul is unified with its own agent intellect (intellectus adeptus), permanently or temporarily, it is then sent forth into the divine light in ignorance (intellectus assimilativus / unum animae). It was in this sense, then, that Berthold presented the unum animae and its cognition through ignorance as the higher operation or phase of the fifth mode in $123 \mathrm{D}$, while the intellectus adeptus is that same mode as directed toward the possible intellect below it. This is consistent with every case examined so far: the two always go together, whether they are enjoyed by a transitory raptus in this life, either by a special grace or after the accomplished habit of the oblique motion, or permanently in patria.

Berthold's transformation of Dietrich's doctrine of beatitude is also consistent what we saw in $188 \mathrm{E}$ and $193 \mathrm{E}$, where the agent intellect was still held to be the soul's proximate essential cause, with the unum animae added as its deeper phase. In one sense, there is very little difference between the intellectus adeptus and the unum animae: once a person has the cognition of the intellectus adeptus, they have the cognition of the unum. But by adding a deeper or higher modality to this cognition, directly under the inspiration of Proclus

69 Most scholars would see this as a significant departure from Albert, although M. Führer, "The Agent Intellect in the Writings of Meister Dietrich of Freiberg and its Influence on the Cologne School", in K.-H. Kandler, B. Mojsisch, B. Stammkötter (eds), Dietrich von Freiberg. Neue Perspektiven seiner Philosophie, Theologie und Naturwissenschaft (Amsterdam: Grüner, 1999), p. 69-88, has argued that Dietrich was a true follower of Albert when he in located the attainment of the acquired intellect only in patria. 
and Dionysius, and perhaps also in line with Albert, Berthold definitively subordinated the reflexive character of the acquired intellect and its identification with self-knowledge to the non-reflexive knowledge through ignorance of the unum. Overall, however, the closest contemporary parallel one can find for the notion of a simultaneous identity and difference of reflexivity and nonreflexivity is not found in Albert or Dietrich, but in a passage from Meister Eckhart's sermon Von dem edeln Menschen (On the Nobleman):

I say that as man, the soul, the spirit, contemplates God, he also knows and perceives himself perceiving; that is, he perceives that he is contemplating and perceiving God. Now some people have thought, and it seems quite plausible, that the flower and core of blessedness consists in knowledge, when the spirit knows that it knows God. For if I possessed all joy, and I did not know it, how could that help me and what joy would that be to me? Yet I say certainly that this is not so. It is only true that without that the soul would not be blessed; but blessedness does not consist in this, for the first thing in which blessedness consists is when the soul contemplates God directly. From there, out of God's ground, it takes all its being and its life and makes everything that it is, and it knows nothing about knowing or about love or about anything at all. It comes to rest completely and only in the being of God, and it knows nothing there except being and God. But when the soul knows and perceives that it contemplates, perceives and loves God, this is in the natural order a going out and a return to the starting point. ${ }^{70}$

70 Meister Eckhart, Liber "Benedictus". Von dem edeln Menschen, in Die deutschen Werke, ed. J. Quint, vol. 5 (Stuttgart: Kohlhammer, 1963), p. 116, l. 21 - p. 117, l. 4: Ich spriche: sô der mensche, diu sêle, der geist schouwet got, sô weiz er ouch und bekennet sich bekennende, daz ist: er bekennet, daz er schouwet und bekennet got. Nû hât gedunket etlîche liute und schînet gar gelouplich, daz bluome und kerne der saelicheit lige in bekantnisse, dâ der geist bekennet, daz er got bekennet; wan, daz ich alle wunne haete und ich des niht enwiste, waz hülfe mich daz und waz wunne waere mir daz? Doch enspriche ich sicherliche des niht. Aleine ist daz wâr, daz diu sêle âne daz doch niht saelic waere, doch enliget diu saelicheit dar ane niht; wan daz êrste, dâ saelicheit ane geliget, daz ist, sô diu sêle schouwet got blôz. Dâ nimet si allez ir wesen und ir leben und schepfet allez, daz si ist, von dem grunde gotes und enweiz von wizzenne niht noch von minne noch von nihte alzemâle. Si gestillet ganze und aleine in dem wesene gotes, si enweiz niht dan wesen dâ und got. Sô si aber weiz und bekennet, daz si got schouwet, bekennet und minnet, daz ist ein ûzslac und ein widerslac ûf daz êrste nâch natiurlîcher ordenunge. English translation: Meister Eckhart, The Essential Sermons, Commentaries, Treatises, and Defense, trans. E. Colledge, B. McGinn (Mahwah: Paulist Press, 1981), p. 245. 
Eckhart did not deny that reflexivity is a necessary aspect of beatitude. Rather, he took issue with the argument that beatitude consists primarily in the reflexive knowledge whereby one knows that one knows God. In some sense, as Eckhart acknowledged, one can understand why a person would suppose that reflexivity alone is both necessary and sufficient for beatitude - if I had all the joy or riches in the world and was not aware of it, what good would that be to me? In other words, as we saw for Dietrich and Berthold in contrast to the Ler von der selikeyt, beatitude is only beatitude when it is communicated to the entire soul. But what Eckhart was arguing was that there is in beatitude a kernel of non-reflexivity in which the soul, in all of its powers, is completely oriented toward God and not to itself; this is the root of beatitude and the prior moment, so to speak, that makes possible the appropriation of that bliss to the self in reflexivity.

Eckhart made a similar argument and the same criticism in his commentary on the Gospel of John, where he referred to a fuller discussion of the issue in the Opus quaestionum, which is no longer extant. ${ }^{71}$ In his commentary on John 1:12 ("As many as received him, he gave power to become sons of God"), Eckhart began by noting that anything that "receives" or participates something else, insofar as it is receptive, is in itself empty and in a passive potency. The existence of this passive power is completely derived from and dependent upon its object. This is because a potency exists entirely in relation to its activity, and in this case the potency in act has the same act of existence as the object in act. Following Aristotle (De anima III.2, 425b26), Eckhart gave the example of a sense faculty and sense object: both the eye and the object seen become entirely identical in act. ${ }^{72}$ The disproportion in the analogy, which Eckhart thought applied more perfectly to intellectual realities, is that the object seen does not give existence to the eye insofar as it is an eye or a being. Nevertheless, the seeing-eye and the seen-object are intrinsically related to one another in this way. If you take away the seeing-eye, then there is no seen-object, and vice versa. "To see and to be seen" in act "are one and the same thing". Their active union is logically prior to their distinction. The ethical consequences of the

71 Meister Eckhart, Expositio sancti evangelii secundum Iohannem, in Die lateinischen Werke, eds A. Zimmermann, L. Sturlese, vol. 3 (Stuttgart: Kohlhammer, 1994), §106-108 (John 1:12-13), p. 9o, l. 9 - p. 93, l. 8, and $\$ 679$ (John 17:3), p. 593, l. 1 - p. 594, l. 2. These passages clarify the target of Eckhart's criticism. For a discussion of Eckhart in the context of other responses to John of Paris' argument about reflexivity in the beatific vision, see Th. Jeschke, Deus ut tentus vel visus. Die Debatte um die Seligkeit im reflexiven Akt (ca. 1293-1320) (Leiden: Brill, 2011), p. 26o-274.

Cf. K. Flasch, Meister Eckhart. Philosopher of Christianity, p. 37-44, 184-188, 210-213. 
Gospel's natural philosophical truth, as Eckhart presented it, are captured in John 17:3 ("This is eternal life, to know you, the only true God, and Jesus Christ whom you have sent"). That is, to "receive" the Word, a person become entirely like a potency related to its act or, in other words, one must be pure existence for God (deo esse). This is nothing else than to be ignorant of oneself and all else besides God himself and what exists in God that is God himself. This is effectively to participate in the life of the Incarnate Word and, as Eckhart indicated in his opening comments on John 1:12, to be conformed to "the same image". This, he concluded, is what Augustine meant in the Confessiones, when he exclaimed that, "Unfortunate is the person who knows everything else, but does not know you; blessed is the person who knows you, even if he is ignorant of all these things".

The same argument appeared again in a briefer form in Eckhart's commentary on John 17:3, where the two portions of the verse (haec est vita aeterna / ut cognoscant te verum deum solum, etc.) prompted him to discuss the kind of "eternal life" that is proper to the intellectual nature in beatitude. ${ }^{73}$ Here we find one of Eckhart's rare references to the hidden depth of the mind (abditum mentis) of Augustine's De Trinitate, in which the mind always remembers, thinks, and loves God. Immediately after this, Eckhart reiterated the point that beatitude does not consist primarily in a reflexive act, since blessedness consists in being oriented to nothing apart from God.

Interestingly, in Eckhart's summary of his commentary on John's prologue, when he came to the same verse from John 1:12 ("As many as received him", etc.), which first prompted the criticism about reflexivity, he made the only mention in his entire corpus of the doctrine of the intellectus adeptus. He attributed this notion to "the philosophers", as example of how a lower intellectual principle is gradually conformed to a higher intellectual principle - that is, how a person comes to share in the complete relatedness to the Father that is characteristic of the Word: the light of agent intellect penetrates more and more into the imaginative power through a process of extrinsic efficient causality ("alteration"), until the lower is related to it as matter is to form, and the proper operation of the higher is communicated to the lower ("generation"), which has now been transformed "into the same image". ${ }^{4}$

There are of course significant differences in the means by which Eckhart and Berthold arrived at their similar conclusions about non-reflexivity and

73 Meister Eckhart, Expositio sancti evangelii secundum Iohannem, §679 (John 17:3), p. 593, l. 1 - p. 594, l. 2.

74 Meister Eckhart, Expositio sancti evangelii secundum Iohannem, §155 (John 1:12), p. 128, 1. 1-10. 
beatitude. In Eckhart, the soul is oriented non-reflexively to God as being, whereas for Berthold the highest principle in the soul is an image of what is prior to being. For Eckhart, the soul's emptiness or receptivity corresponds to its complete directedness towards God, but for Berthold the unum animae is in each soul as a ceaselessly active principle. While Eckhart did not ignore the mediations or "alterations" that precede birth or "generation", his emphasis fell on their dialectical interrelation - one is temporal and finite, the other is eternal and infinite - which corresponded to his greater stress on the immediacy of the birth, even if it is almost infinitely distant from everyday experience. In the Expositio, however, Berthold located the De mystica theologia and the hidden cognition of the unum animae at the summit of a long and arduous progression of scientific understanding, that eventually reaches the comprehensive vision of the intellectus adeptus and finally moves beyond this into the divine darkness.

What the example of Eckhart does suggest, at least, is that some discussion about reflexivity in the beatific vision was underway in the German Dominican milieu in the mid-1310s and early 1320s, when Eckhart wrote the commentary on John and the Liber "Benedictus". ${ }^{75}$ Similar though their conclusions are, before we hurry to posit any influence, we must acknowledge that a sufficient explanation of Berthold's doctrine and his synthesis of Albert and Dietrich, who were clearly his direct sources, was provided simply by the texts of Proclus (De providentia et fato 8.31-32) and Dionysius (De mystica theologia 1 and 3; De divinis nominibus 7.1). As we proceed further into the Expositio, we will see how this distinction of reflexivity and non-reflexivity was integrated into Berthold's cosmology and theory of deification. Berthold understood Goodness and "the ecstasy of divine love" to be at the root of God's own Trinitarian life and creative will; likewise, an intellectual creature actively exercises providence with the gods in a state that is prior to reflexive understanding, which participates in that same spontaneous action.

As for the three motions of the soul, moreover, the passages on contemplation from $185 \mathrm{~K}-\mathrm{M}$ and $2{ }_{2} \mathrm{C} \mathrm{C}$ show us that the unum animae is a feature not only of the direct motion, but also of the circular motion, which in its perfection is also "immovably fixed on one and the same object" through "the highest intelligence". ${ }^{76}$ Therefore, whenever Berthold used the term intelligentia, which he

75 On the dating of both works, see Meister Eckhart, Das Buch der göttlichen Tröstung, trans. K. Flasch (München: Beck, 2007), p. 120-121.

76 Berthold of Moosburg, Expositio, 185K-M, p. 25, l. 384 - p. 28, l. 471, especially p. 28, l. 45746o: anima [partialis] non semper movetur motu circulari, ut fiat informis uniens se unitis virtutibus, nec semper est statuta se tota extra se totam et supra se totam in unitionem excedentis mentis, per quam coniungitur diis per recursum sui ad summam intelligentiam; 
found in Proclus and Boethius, we should understand by it the combination of the intellectus adeptus and the unum animae or, in other words, the intellect in its providential operation. Notwithstanding his use of Thomas of York's description of the circular motion at $131 \mathrm{~A}$, where it was identified as the restless heart's search for God, Berthold seems have preferred the account he discerned in Proclus and Boethius, which made the circular motion identical in content to the direct motion, except for the fact that it does not begin from the senses. This interiority what makes it most appropriate for the heavenly souls. A human soul partakes of the circular motion to the extent that it can separate itself from the body, quieting itself and beholding its innate content that has been recollected through prior learning (the oblique motion). The direct motion then amounts to the rapid or possibly instantaneous progression along the same path charted arduously by the oblique motion, from creatures to their source in the supersubstantial world. The unum animae is more closely associated with the direct motion in the Expositio tituli and 131A because, when creatures have become transparent to their source, it is a sign that the unum animae has been awakened.

While for Berthold it is indisputable that Proclus exercised all three motions through "the guidance of the natural light of the intellect" (as is said the Expositio tituli), from ${ }_{13} 1 \mathrm{~A}$ it has become clear that there is an order among these motions, and that the oblique almost always precedes the direct motion. Following 185 and 202, we may infer further that the circular motion, understood through Proclus rather than Thomas' account given in 131A, is not immediately accessible to the soul. We cannot deny that for Berthold Platonic philosophy was meant to be argumentatively defended and made available to the rational creature as such, rather than merely being founded on an inscrutable experience - for Berthold, that was the entire point of the Elementatio theologica and the oblique motion. But we should not conclude from ${ }_{13} 1 \mathrm{~A}$ that the

202C, p. 186, l. 152-170: Hae [animae totales] enim non recurrunt aliquando ad ipsam summam ipsarum intelligentiam, sed firme et indeclinabiliter secundum statum suum perpetuum in ipsa stant, per quam, ut dicit auctor loquens de una et singulari anima libro De fato et providentia, cap. 6 in fine, 'videt quidem sorores ipsius [...].' Haec auctor, qui licet loquatur de contemplatione possibili animae in vita praesenti, tamen nihilominus verum est de contemplatione aeternali, prout talis contemplatio stat fixa immobiliter et secundum unum et idem obiectum. Talis enim anima simplicem et beatum adepta intellectum sive in sui in esse constitutione, sicut omnis anima totalis se habet, sive sui ab hoc ergastulo liberatione operans contemplatione divinissima, qualis est anima humana beata, omnis, inquam, talis anima non est quietans se ipsam ab exterioribus motibus vel interioribus, qui nulli ibi sunt, sed deus facta, ut animae possibile, cognoscet solum, qualiter dii omnia indicibiliter cognoscunt singuli secundum le unum, quod sui ipsorum. 
providential cognition of the unum animae in the direct or circular motion automatically follows from the perfection of the oblique motion. Berthold's stronger affirmation about the possibility of contemplation in this life, building on Dietrich's passing reference to Benedict's vision of the cosmos in a single ray of light, was conceived in terms of a raptus that coincided with the Dionysian and Proclean instructions about silencing every intellectual operation in order to be made receptive for God's activity in the soul. ${ }^{77}$ While souls animating the heavens "possesses [adepta] a simple and blessed intellect" by nature through a gift of God, this possession comes to human souls only "by liberation from this prison-house", when the soul will achieve a stillness beyond striving. ${ }^{78}$

Berthold read Dietrich and Thomas in light of each other: from Thomas he took the view that the philosophers had in fact arrived to a direct vision of God; following Dietrich, he understood this in terms of the transitory enjoyment in this life of the acquired intellect and, going beyond Dietrich to the Platonists, of its non-reflexive ground. Whether by a "special grace" to one who was seemly unprepared, like Paul on the road to Damascus, or to one how has perfected the oblique motion, like Proclus, this transitory vision was given (datus). The difference, therefore, must consist in the fact that the perfected oblique motion, the work of laborious study and investigation into divine realities, better disposes the soul to receive that gift. But if we construe the transition from the oblique motion to the higher and deifying motions as only an automatic process, we risk obscuring the centrality of raptus in Berthold's contemplative theory. As we saw in Chapter 1, rapture so integral to his understanding of contemplative union that it featured at the beginning of the Prologus, with Paul (summus divinalis sapientiae theologus Paulus [...] raptus), and at its conclusion, with the final stage of the restless and arduous ascent to God found in Psalm 42, when the soul is lifted beyond itself to intelligentia and the unum animae as the hart is drawn up to the water-brooks (rapitur sicut cervus). ${ }^{79}$

This relation of reason and grace can be clarified further if we consider the fundamentally Boethian character of Berthold's treatment of the goal or final cause of the Elementatio theologica in the Expositio tituli. ${ }^{80}$ Using the Consolatio philosophiae, Berthold compared Proclus' propositions to the ladder depicted on Lady Philosophy's garment, by which the "contemplator" ascends from "the

\footnotetext{
77 Berthold of Moosburg, Expositio, 202B, p. 185, l. 132-144; 211E, p. 264, l. 222-228.

78 See n. 76 , above.

79 Berthold of Moosburg, Expositio, Prol. 1, p. 5, l. 5-6; Prol. 20, p. 34, l. 964-965. Cf. 211E, p. 263, 1. 215-218: non fit secundum habitum permanentem in hac vita, licet raptim et secundum quendam transitum fiat aliquibus. 
divine by participation" to "the divine by essence" (the gods) and from there to "the divine as cause" (God). As Lady Philosophy taught, the contemplation of the fount of all goods, where all things are held together at once (cuncta simul), makes a person not only blessed (beatus), "but even god" (sed etiam deus) by participation. Berthold went on to relate the $\Pi$ and $\Theta$ depicted on her garment, representing the practical and theoretical lives, to Augustine's report that Plato's philosophy strove both for moral and rational perfection (opus et scientia). Finally, citing Avicebron, Berthold declared that the "final cause of humankind" is "the striving to the higher world", achieved through "knowledge and activity" (scientia et operatio), which "liberate the soul from the captivity of nature, [and] cleanse it from its darkness and obscurity". This emphasis on intellectual and moral ascesis culminated with a brief prayer: "that we may ascend through this [the vision of the primordial causes] to contemplate the highest Good, the primarily Good, may we be carried across with his support, who is the mediator of God and humanity, Jesus Christ". If we are to interpret these passages as something more than rhetorical ornamentation, which we certainly must do in view of Berthold's allegiance to Dietrich of Freiberg's conception of beatitude and the role of grace, then we must conclude that, for the passage from the dividedness of reason (the oblique motion) to the unified vision of the acquired intellect and the unum animae - the vision of the divine light as at once beginning, middle, and end of all things at the end of the Prologus; or the deifying vision of all goods cuncta simul here at the conclusion of the Expositio tituli - divine assistance is required for the natural light of reason to realise its hidden and natural operation. Just as, "with Plato and Boethius", he understood that the divided cannot unify itself, and so too he could acknowledge that for Proclus deification occurs through grace. ${ }^{81}$ As Berthold saw it, then, the purpose of the Elementatio theologica, was to help the soul build the speculative habit, the discursive awareness and science of the primordial causes and the hidden depth in the soul's own ground, that will dispose it to receive the vision of all goods cuncta simul.

Berthold's conception of a doctrine of grace that was internal to ancient Platonism is consistent with his transformation of the doctrine of double providence that he inherited from his German Dominican predecessors. The central text introducing this notion is Expos. tit. I, but once again we must supplement Berthold's preface with other passages from his commentary for a 
complete account. Berthold explicitly referred to either providentia naturalis or providentia voluntaria in 41 subsections of his commentary, and in all but ten he treated them as a pair. The brief entries for providentia and providentia naturalis in the Tabula contentorum (there is no entry for providentia voluntaria) helpfully point the reader to Proposition 120 , where the theme of providence is first introduced by Proclus, and to Proposition 141 where, according to his commentator, Proclus "shows that providence is twofold".

Berthold generally acknowledged that the origin of the distinction was found in Augustine (De Genesi ad litteram viII.9.17). Only in 141A, however, did he provide a full quotation of the relevant text. Commenting on Genesis 2:15 ("And the Lord God took man, and placed him in the Paradise Eden, to work upon it and maintain it [ut operaretur et custodiret illum]"), and casting the mind's eye upon the universe likened to a great tree of beings (quamdam magnam arborem rerum), Augustine distinguished between God's "hidden governance" that "gives growth to trees and plants", and that which governs voluntary agents, such as angels and humans. ${ }^{82}$ The heavens and the earth are ordered by the first, which extends to "anything that is borne by an interior natural motion". The second pertains to agriculture, to the arts, and the ordering of societies both angelic and human. Berthold paraphrased the first as "the order and connexion of essential and substantial causes" (ordo et conexio causarum essentialium et substantialium).

This phrase shows the influence on Berthold of Dietrich of Freiberg (causa essentialis) and Ulrich of Strassburg who, following Albert the Great, used the Hermetic definition of fate as a conexio causarum. ${ }^{83}$ The importance of Ulrich as the originator of this formative interpretation of Augustine in the German Dominican context has recently started to receive due attention from scholars. ${ }^{84}$ This was not lost on Berthold, who began Proposition 120, the central passage signalled by the index, with a citation from Ulrich:

82 Berthold of Moosburg, Expositio, 141A, p. 45, l. 11-26.

83 The principal text in Albert the Great is Physica, lib. II, tr. 2, c. 19, p. 126, 1. 25-40. See also Albert the Great, De fato, ed. P. Simon (Münster i.W.: Aschendorff, 1975), a. 2, p. 68, l. 1-4. On these texts, see A. Palazzo, "The Scientific Significance of Fate and Celestial Influences in Some Mature Works by Albert the Great. De fato, De somno et vigilia, De intellectu et intelligibili, Mineralia", in A. Beccarisi, R. Imbach, P. Porro (eds), Per perscrutationem philosophicam, p. 55-78; id., "Albert the Great's Doctrine of Fate", in L. Sturlese (ed.), Mantik, Schicksal und Freiheit im Mittelalter (Köln: Böhlau, 2011), p. 65-95; id, "Regna duo duorum. Berthold of Moosburg's Theory of Providence and Fate”, forthcoming.

84 Beccarisi, "La scientia divina dei filosofi"; ead., "Einleitung", in Ulrich of Strassburg, De summo bono. Liber 2, Tractatus 5-6, ed. A. Beccarisi (Hamburg: Meiner, 2007), p. xvi-xx; Ferro, "Berthold of Moosburg, Reader of Ulrich of Strassburg", forthcoming. 
Although the primarily Good, the God who is beyond-blessed beyond all things, makes all things primarily through himself and governs them through providence, nevertheless, in order that the dignity of causality and divine cooperation, which is the most divine of all works, be not absent from the universe (to which all levels of divine goodness that can possibly exist are communicated), God also works through causes that are second to himself, that is, through the primordial causes. And these are ordered in two ways according to the double mode of providence, which Augustine distinguishes in Book 8 of his Hexaemeron, saying that 'the twin activity of providence is found to be partly natural, and partly voluntary'. ${ }^{85}$

Berthold then juxtaposed Augustine's vertical distinction with the horizontal subordination of fate to providence in Boethius and Proclus. ${ }^{86}$ Boethius identified providentia with the order of causes as they are beheld in the simplicity and stability of the divine mind, and fatum with the explicated, manifold, and temporal disposition of causes in the sensible world. As Lady Philosophy instructed the prisoner in the Consolatio, to the extent that a person seeks satisfaction in inherently divided and transitory goods, they will remain subjected to fate. For Boethius and Proclus, entities nearer to the One are embraced only by providence, and are exempt from the fated, variegated connection of causes. A person will be free only to the extent that he draws nearer to the divine origin and mode of cognition that constitutes providence. Yet for Ulrich and Berthold, there is a sense in which the highest secondary causes, the primordial causes, are both fated, as explicated from the divine mind, and providential, in that they participate and cooperate directly

85 Berthold of Moosburg, Expositio, 120E, p. 100, l. 295-302. Cf. Ulrich of Strassburg, De summo bono, ed. A. Beccarisi, lib. II, tr. 5, c. 18 (9), p. 145, l. 258 - p. 146, l. 265: Licet prime bonum super omnia superbenedictus Deus per se principaliter omnia efficiat et per providentiam gubernet, tamen, ut dignitas causalitatis et divinae cooperationis, quae est divinissimum operum, non deesset universo, cui communicati sunt omnes gradus divinae bonitatis possibiles existere, operatur etiam per secundas causas a se, scilicet per primordiales. Et istae sunt ordinatae dupliciter secundum duplicem modum providentiae, quae distinguit Augustinus VIII Hexaemeron sui dicens, quod 'gemina operatio providentiae invenitur, partim naturalis, partim voluntaria!

86 Gersh, Middle Platonism and Neoplatonism, vol. 2, p. 701-705, argues that while the extent of Proclus' influence on Boethius has been debated, on the question of providence and fate that influence is effectively beyond dispute. Berthold was perhaps the first scholar to note the connection at Expositio, 141B, p. 46, l. 42 - p. 48, l. 109. On this passage, see A. Palazzo, "Regna duo duorum". 
in God's power. ${ }^{87}$ One way to resolve this ambiguity between the two models would be to say that, for Berthold, fate and providence are only distinct where the operation of a thing differs from its essence - that is, either in the sensible world or among accidental and volitional agents like angels and human individuals. In this way, we may assume that Berthold intended to superimpose both the Augustinian and Boethian models of providence: the human being is subject to fate in becoming, but begins to exercise providence with the gods when it is capable of raising its contemplation to the stable order of being.

The other major source for Berthold's interpretation of gemina providentia was a fragment (MS Basel, Universitätsbibliothek, F.Iv.31, f. 69va-vb), which Berthold himself copied. Loris Sturlese has identified it as a portion of a lost treatise by Dietrich of Freiberg, the De subiecto theologiae listed in the early catalogues of Dietrich's works, and there are no solid reasons to doubt this attribution. ${ }^{88}$

The fragment appears to contain Dietrich's determination of a question concerning the unity of theological science..$^{89}$ Its references to "partial books" and "treatises" suggest that the fragment derived from a prologue to a larger theological work, perhaps a Sentences commentary. ${ }^{90}$ It begins by using the example of the physical sciences in order to outline the different kinds of unity that a science may possess. ${ }^{91}$ Following "hearsay and probability" rather than "properties of the things themselves and the manifold truth of reflection", some have held "by a logical reflection" that things as diverse as the incorporeal and the corporeal can be treated under a single, univocal genus (i.e., substance). Dietrich rejected this approach and argued that the structural unity of a science must conform to the realities themselves. For,

87 Berthold of Moosburg, Expositio, 114B, p. 43, 1. 92-94: Inquantum tamen prime bonum explet providentiam suam per primordiales causas, sic actus providentiae primitus est in diis [...] et per consequens nomen Dei. Cf. Ulrich of Strassburg, De summo bono, lib. II, tr. 5, c. 16 (5), p. 110, l. 6o-61: Inquantum tamen providentiam suam Deus explet per fatum, sic actus providentiae participantur a creaturis, et per consequens nomen Dei.

88 Sturlese, "Introduzione", p. xvi-xxxiv; Dietrich of Freiberg, Opera omnia, vol. 3, p. 277; Flasch, Dietrich von Freiberg, p. 502.

89 Dietrich of Freiberg, De subiecto theologiae, ed. L. Sturlese, 2.2, p. 279, l. 10: in proposito circa subiectum naturalis scientiae considerandum; 3.1, p. 28o, 1. 33-34: tertio sumendum in proposita quaestione.

90 Dietrich of Freiberg, De subiecto theologiae, 3.3, p. 28o, 1. 44-58.

91 Dietrich of Freiberg, De subiecto theologiae, 2.2, p. 279, l. 10: Sic in proposito circa subiectum naturalis scientiae considerandum; 3.1-2, p. 28o, l. 33-36: Tertio sumendum in proposita quaestione proprium subiectum et ipsius unitatem, quo etiam ipsa scientia theologica unitatem habet. Ubi considerandum, quod sicut in his, quae gratia exempli seu manuductionis praemissa sunt in rebus naturae [...]. 
as Aristotle showed, physics cannot have a univocal and logical unity since one cannot subsume heavenly and sublunary beings univocally under one genus; as Averroes clarified, their properties stand in a completely equivocal relation to one another. Instead of a univocal and logical unity, then, Dietrich proposed a unity of proportionality (proportionalitas), where A:B :: C:D. That is, just as sublunary bodies are composed of their principles, so analogously heavenly bodies are composed of theirs. Motion and other natural properties are comparable only according to the notions of their respective principles within each genus.

Dietrich then made the distinction that Berthold would follow in the Expositio tituli between a science's subject (subiectum) and its matter (materia). Dietrich first discussed natural substance, and then reasoned about how the structure of the science should follow from this. ${ }^{92}$ Among natural beings, any one of the principles or components from which a substance is constituted may be considered by itself, such that it is understood to relate to its unifying substance as a kind of "matter". Alternatively, the aggregate of principles may be considered under the aspect of the whole, and thus as "something complete, existing in act according to one formal reason", which "is subject [subicitur] to an agent and the properties bestowed by the agent". Failing to observe this distinction between subject and matter in theology, Dietrich continued, the less circumspect (minus considerantes) have supposed its subject must be something particular like totus Christus, res et signa, "the works of creation and restoration", or even "God himself". For Dietrich, these are in fact the particular "matters" which are integrated into a more comprehensive whole or "subject" by virtue of "a notion common to all". These different "matters" are related by proportionality so that, as in the physical sciences, they must be reduced to the unity of proportion or attribution to some single term (ad aliquod unum). For example, just as rewards are due to the just, so penalties are to the wicked; just as God will judge the good, so he will judge the wicked. These proportionalities must be reduced to a common unity that is the basis for the analogy. As an example of this correct procedure, Dietrich cited Proposition 21 of the Elementatio theologica, on the four genera or maneries of nature, soul, intellect, and the One, and Proclus' reduction of all agreement to some one that is the primary analogate or root and principle (radix et ratio) of the order. ${ }^{93}$

92 Dietrich of Freiberg, De subiecto theologiae, 3.1-4, p. 28o, 1. 33 - p. 281, l. 68.

93 See also Dietrich of Freiberg, De cognitione entium separatorum, ed. H. Steffan, in R. Imbach et al. (eds), Opera omnia, vol. 2. Schriften zur Metaphysik und Theologie (Hamburg: Meiner, 1980), 74.2-3, p. 237, l. 99-110. 
In this science (in hac scientia), Dietrich continued, "the whole universe of beings" is treated, either according to the order of natural providence or voluntary providence. ${ }^{94}$ The subject that unifies its various "matters" is divine being (ens divinum), which primarily, simply, and essentially belongs to God. Other things are and are said to be divine by analogical attribution. Examples of this kind of attribution come from Averroes (In Metaphysicam IV, comm. 2), who used the familiar example of health: plants and medicine are the efficient causes of health by attribution, that is, by virtue of their relation, to the art of medicine; exercise is called "healthy" because health is its final cause; finally, accidents are attributed to a substance as to a subject, as something "more formal" that properly has the notion of "being", while the accidents themselves are "dispositions of being". Thus, "beings are attributed to God" as their principle (efficient cause), as their end (final cause) and even in the third sense as accidents are to their subject, insofar as sacramental actions are performed in persona Christi with regard to the works of salvation and redemption.

Dietrich then introduced the two orders of providence to distinguish between two kinds of theology, the theology of the philosophers and "our theology of the saints". ${ }^{95}$ The philosophers, he observed, use precisely this kind of analogical consideration in their first philosophy, which they call "divine science or theology" rather than "metaphysics" because ens divinum belongs first to what is "divine by essence" and secondarily to the ordered universe in relation to it. Nevertheless, "our science, which truly and simply we call theology, is distinguished from the divine science of the philosophers". For the philosophers' divine science considers the universe only relative to "natural providence", according to which the first cause governs things by their innate modes and natural properties. In this perspective, beings are not understood relate to an end beyond the order of nature. "Our divine science of the saints", however, views beings under the order of "voluntary providence", in which are found the notions of merit and reward, as well as matters bearing on a good and holy life and the attainment of eternal bliss. This divine science looks to an end beyond the limits of this world, "when the divine science of the wise of this world is destroyed". 96

94 Dietrich of Freiberg, De subiecto theologiae, 3.5-7, p. 281, l. 69-91. See n. 122, below.

95 Dietrich of Freiberg, De subiecto theologiae, 3.8-10, p. 281, 1. 92 - p. 282, 1. 112.

96 Dietrich of Freiberg, De subiecto theologiae, 3.9, p. 281, l. 100 - p. 282, l. 109: Scientia enim divina philosophorum considerat universitatem entium secundum ordinem providentiae naturalis, quo videlicet res stant in sui natura et secundum suos modos et proprietates naturales gubernantur per principem universitatis, nec ultra hunc naturae ordinem aliquem ulteriorem finem attendit. Nostra autem divina sanctorum scientia attenditur in entibus, secundum quod stant et disponuntur sub ordine voluntariae providentiae, in quo attenditur 
Because of this final argument, the fragment has come to occupy an uneasy place in Dietrich's corpus. Without directly denying its authenticity, Kurt Flasch has argued that the short text displays internal and external inconsistencies. ${ }^{97}$ The internal ones, "which the writer of the fragment did not notice",98 appear relative to the unity of theology itself - a potentially devasting criticism, as this was ostensibly the text's primary concern. Flasch is right to note that Dietrich presented us simultaneously with a unified picture of theology (in hac scientia) embracing both orders of providence grounded in an analogical model culminating in ens divinum, alongside his claim that "our divine science of the saints" differs from pagan divine science. But this apparent inconsistency can be addressed, for we have seen already that Dietrich argue that several physical sciences (in physicis) can be placed under the singular heading of natural philosophy (philosophia naturalis) which, just as in the consideration of theology, is referred to using the phrase in hac scientia. ${ }^{99}$ The fragment uses this formal model applied to both natural philosophy and theology, based on the distinction between matter and subject, in the rationalistic and combative way we would expect of Dietrich. ${ }^{100}$ That is, it prefers a pagan philosopher's understanding of the formal structure theology to the models of "the less circumspect", who would include no lesser authorities than Augustine, Cassiodorus, Hugh of St. Victor, and Thomas Aquinas! While Proclus' model of proportionality, in which various matters are analogically united by a common subject (ens divinum), is the most adequately conformed to the nature of things, the limitation of the content of his theology, according to the fragment, is that it does not see that human freedom and the ethical life relates to an order beyond the confines of natural necessity.

The concern about the apparent internal and external doctrinal inconsistencies in the De subiecto theologiae is, however, related to a larger question about its relation to the methodology of natural and voluntary providence in Dietrich's works as a whole. ${ }^{101}$ It is often assumed that the precedent for

ratio meriti et praemii et ea, quae attenduntur circa bonam et sanctam vitam et adeptionem aeternae beatitudinis et perventionem ad finem ulteriorem sive in bono sive in malo etiam post terminum huius mundi, quando scientia divina sapientium huius mundi destruetur, I Cor., 13.

97 Flasch, Dietrich von Freiberg, p. 502-512. See also C. König-Pralong, Le bon usage des savoirs. Scolastique, philosophie et politique culturelle (Paris: Vrin, 2011), p. 250-252.

98 Flasch, Dietrich von Freiberg, p. 509.

99 Dietrich of Freiberg, De subiecto theologiae, 2.2-3, p. 279, 1. 10-29.

100 Cf. Flasch, Dietrich von Freiberg, p. 563; König-Pralong, Le bon usage des savoirs, p. 248.

101 Sturlese, "Introduzione", p. xxvi-xxxiv; id., "Il De animatione caeli di Teodorico di Freiberg", in R. Creytens, P. Künzle (eds), Xenia Medii Aevi historiam illustrantia, oblata Thomae Kaeppeli O.P., 2 vols (Roma: Edizioni di Storia e Letteratura, 1978), vol. 1, p. 175-247, at 
Dietrich's methodology should be sought primarily in Albert's philosophical commentaries. ${ }^{102}$ As for the De subiecto theologiae itself, most scholars generally minimise its importance for Dietrich's thought, or use it only as a confirmation of Dietrich's commitment to the methodological autonomy of natural philosophy. Others have pushed in the opposite direction, and argued that Dietrich's philosophical works should rather be understood as preparatory and provisional in relation to his theology oeuvre which, alas!, is largely no longer extant. Dietrich's position, as I understand it, was somewhere in the middle of these two options. In my view, it is largely thanks to the De subiecto theologiae that we can appreciate one of the most fascinating aspects of Dietrich's methodology throughout his works: his hypothetical approach to the philosophy of the separate substances.

p. 183-197; R. Imbach, "Metaphysik, Theologie und Politik. Zur Diskussion zwischen Nikolaus von Strassburg und Dietrich von Freiberg über die Atrennbarkeit der Akzidentien", in Theologie und Philosophie 61(1986), p. 359-395; A. de Libera, "Philosophie et théologie chez Albert le Grand et dans l'école dominicaine Allemande", in A. Zimmermann (ed.), Die Kölner Universität im Mittelalter (Berlin: De Gruyter, 1989), p. 49-67; Sturlese, Storia della filosofia tedesca nel Medioevo, p. 204-213; C. Trottmann, "La théologie des théologiens et celle des philosophes", in Revue thomiste 98(1998), p. 531-561; K.-H. Kandler, "Theologie und Philosophie nach Dietrich von Freibergs Traktat De subiecto theologiae", in J. Aertsen, A. Speer (eds), Was ist Philosophie im Mittelalter?, p. 642-647; id., "Theologische Implikationen der Philosophie Dietrichs von Freiberg", in K.-H. Kandler, B. Mojsisch, B. Stammkötter (eds), Dietrich von Freiberg. Neue Perspektiven, p. 121-134; T. Suarez-Nani, "Substances séparées, intelligences et anges chez Thierry de Freiberg", in K.-H. Kandler, B. Mojsisch, B. Stammkötter (eds), Dietrich von Freiberg. Neue Perspektiven, p. 49-67; K.H. Kandler, "Anima beata vel homo glorificatus possit progredi in aliquam naturalem cognitionem. Bemerkungen zu eschatologischen Gedanken des Dietrich von Freiberg, vor allem zu seinem Traktat De dotibus corporum gloriosorum", in J. Aertsen, M. Pickavé (eds), Ende und Vollendung. Eschatologische Perspektiven im Mittelalter (Berlin: De Gruyter, 2002), p. 434-447; T. Suarez-Nani, Les anges et la philosophie. Subjectivité et fonction cosmologique des substances séparées à la fin du XIIIe siècle (Paris: Vrin, 2002); De Libera, Métaphysique et noétique, p. 344-349; Beccarisi, "La scientia divina dei filosofi"; Flasch, Dietrich von Freiberg, p. 191-193, 512-514, 573-584; C. König-Pralong, "Dietrich de Freiberg, métaphysicien allemand antithomiste", Revue thomiste 108(2008), p. 57-79; Führer, M., Gersh, S., "Dietrich of Freiberg and Berthold of Moosburg", in S. Gersh (ed.), Interpreting Proclus. From Antiquity to the Renaissance (Cambridge: Cambridge University Press, 2014), p. 299-317, at p. 308-309.

102 Cf. Albert the Great, De generatione et corruptione, ed. P. Hossfeld (Münster i.W.: Aschendorff, 1980), lib. I, tr. 1, c. 22, p. 129, l. 13-16: Si autem quis dicat, quod cessabit voluntate dei aliquando generatio, sicut aliquando non fuerit et post hoc coepit, dico, quod nihil ad me de dei miraculis, cum ego de naturalibus disseram; id., Metaphysica, lib. XI, tr. 3, c. 7 , p. 542, 1. 25-28: Theologica autem non conveniunt cum philosophicis in principiis, quia fundantur super revelationem et inspirationem et non super rationem, et ideo de illis in philosophia non possumus disputare. 
The polemical agenda of the most relevant of Dietrich's writings on this question should be kept in mind. ${ }^{103}$ In the triptych of treatises De tribus diffcilibus quaestionibus, Dietrich mounted an assault on an anonymous group of communiter loquentes ("run-of-the-mill babblers") for their failure to observe the methodological distinction between natural and revealed theology: in De animatione caeli, he rejected the widespread claim that angels rather than souls move the heavenly bodies; in De visione beatifica, he targeted the thesis that the beatific vision occurs through the possible intellect; and in De accidentibus, he ridiculed the notion that an accident could subsist apart from its subject. ${ }^{104}$ In each case, Dietrich implied that the promotion of a certain philosophical position out of theological scruples (the Scriptures do not mention heavenly souls, therefore angels must move the heavens; in the beatific vision, God stands in for the agent intellect, the noblest part of the soul; extended quantity serves as a surrogate substance for other accidents in the Eucharistic transformation) has detrimental consequences for reason itself. Dietrich held that if exceptions were made haphazardly to the assumption that the universe has a rational order, with intelligible rules and patterns, then the entire philosophical edifice would be compromised. Dietrich's rationalism was captured by the motto he ascribed to Augustine at pivotal points in his works, either at their outset or when fictive interlocutors challenged him for straying far beyond what is permitted by the letter of Scripture: "Whatever is to be posited by right reason, God should be said to have done" (quidquid recta ratione ponendum est, Deum fecisse fatendum est). ${ }^{105}$ By allowing theological scruples to influence metaphysical argumentation, these thinkers effectively undermine the coherence and certitude of theological science. As Kurt Flasch has put it, Dietrich developed Augustine's notion of gemina providentia into a methodology that insulated "immanent-philosophical inquiries against

103 König-Pralong, Le bon usage des savoirs, p. 228-231.

104 Dietrich of Freiberg, Tractatus de tribus difficilibus quaestionibus. Prologus generalis, ed. L. Sturlese, in Opera omnia, vol. 3, p. 9, 1. 4-6: De tribus articulis de numero difficilium quaestionum importunitate requirentium cogor scribere, a quo supersedere debui propter communiter loquentes.

105 Dietrich of Freiberg, De animatione caeli, ed. L. Sturlese, in Opera omnia, vol. 3, 1.2, p. 13, 1. 7-9; id., De cognitione entium separatorum, 9.3, p. 176, 1. 82-85; id., De intellectu et intelligibili, II.20.2, p. 16o, l. 4-8; id., De substantiis spiritualibus et corporibus futurae resurrectionis, ed. M.R. Pagnoni-Sturlese, in Opera omnia, vol. 2, 28.10, p. 329, 1. 85-86. Cf. Augustine, De libero arbitrio, lib. III, c. 5, §13: Quicquid enim tibi vera ratione melius occurrerit scias fecisse deum tamquam bonorum omnium conditorem. Dietrich's phrasing has a precise parallel in Henry of Ghent, Quodlibet IV, eds G. Wilson, G. Etzkorn (Leuven: Leuven University Press, 2011), q. 10, p. 82, l. 186-187. 
theological intervention". ${ }^{106}$ Rather than isolating the two disciplines, this became an instrument of critique, "a metaphysical sublimation of revealed theology", in which metaphysics could correct theological doctrine. ${ }^{107}$

These points are undeniable. But they must be balanced by another important aspect of Dietrich's methodology, namely, his self-critical approach to the use of these rules as he repeatedly noted the hypothetical character of reasoning according to necessary relations. ${ }^{108}$ In over 40 different passages concerning the existence of the separate intelligences or the heavenly souls posited by the philosophers, Dietrich added some version of the caveat "if they exist".09 Using a similar turn of phrase, Dietrich stated repeatedly that we "rationally conjecture" about such things as the existence of heavenly souls. ${ }^{110}$ In other words, following the dictates of reason and the principles of mediation and proportionality, their existence is necessary. ${ }^{111}$ However, as Dietrich routinely

106 K. Flasch, "Einleitung", in Berthold of Moosburg, Expositio super Elementationem theologicam Procli. Prologus, Propositiones 1-13, p. xi-xxxviii, at p. xxxi; id., Dietrich von Freiberg, p. 191-193, 342, 506, 512-514.

107 Flasch, Dietrich von Freiberg, p. 563; König-Pralong, Le bon usage des savoirs, p. 248.

108 This aspect has been noted by Sturlese, "Il De animatione caeli", p. 220-221, as well as Suarez-Nani, Les anges et la philosophie, p. 64; Flasch, Dietrich von Freiberg, p. 204-206, 284, 299-300, 310; König-Pralong, Le bon usage des savoirs, p. 247-248.

109 Dietrich of Freiberg, De cognitione entium separatorum, 1.3-4, 2.3, 3.1, 5.2-3, 14.1, 27.2-3, 36.2, 37.1, 37.8, 39.2, 39.4, 44.9, 86.6; id., De substantiis spiritualibus et corporibus futurae resurrectionis, 1.1, 1.3, 1.5, 2.2, 6.2, 9.1, 16.1, 18.2, 19.3, 23.4, 28.4; id., De animatione caeli, 7.5, 9.1, 11.4, 15.1; id., De visione beatifica, 3.2.9.2 (4), 3.2.9.8 (1), 4.2.1 (14); id., De intellectu et intelligibili, II.34.1, III.25.1, III.30.2; id., De mensuris, ed. R. Rehn, in Opera omnia, vol. 3, 2.11, 2.43, 8.3; id., De origine rerum praedicamentalium, ed. L. Sturlese, in Opera omnia, vol. 3, 1.14, 3.37; id., Quaestio utrum in Deo sit aliqua vis cognitiva inferior intellectu, ed. M.R. Pagnoni-Sturlese, in Opera omnia, vol. 3, 1.1.4, 1.3.4; id., De dotibus corporum gloriosorum, ed. L. Sturlese, in Opera omnia, vol. 2, 24.5; id., De accidentibus, ed. M.R. Pagnoni-Sturlese, in Opera omnia, vol. 3, 8.2.

110 Dietrich of Freiberg, De animatione caeli, 5.3, p. 16, l. 20: rationabiliter conicimus; 20.1, p. 30, 1. 78: rationi, qua conicimus; id., De cognitione entium separatorum, 44.9, p. 210, l. 101: rationabiliter conicitur; 81.4, p. 243, 1. 97: rationabiliter conicitur; id., De dotibus corporum gloriosorum, 13.3, p. 279, l. 30: rationabiliter conicitur; id., De magis et minus, eds R. Imbach, H. Steffan, in Opera omnia, vol. 2, 14.3, p. 58, 1. 75: rationabiliter conicitur; id., De substantiis spiritualibus et corporibus futurae resurrectionis, 11.1, p. 311, l. 76-77: possumus et de eis conicere tamquam a simili ex tertia manerie entium conceptionalium; 14.1, p. 313, l.1314: aliqualiter conicere possumus de locis dictorum entium realium; id., De visione beatifica, 4.1 (6), p. 106, 1. 33-34: tamen circa hoc probabiliter ex ratione conicere.

111 On the law of mediation (lex divinitatis), see Dietrich of Freiberg, De visione beatifica, prooem. (2), p. 13, l. 14-27. Cf. Albert the Great, Super Dionysium De caelesti hierarchia, eds P. Simon, W. Kübel (Münster i.W.: Aschendorff, 1993), p. 2, l. 19: Haec enim est lex divinitatis, ut per prima media, et ultima per media reducantur. 
acknowledged, even though the existence of these separate principles was regarded by reason as necessary, it cannot not be asserted with certainty.

We should give these claims their full weight when attempting to situate the De subiecto theologiae within Dietrich's larger corpus. ${ }^{12}$ The hypothetical character of Dietrich's thought on these matters explains why he would use metaphysics to critique certain theologians while simultaneously subordinating the theology of the philosophers to "our theology of the saints", and even go so far to speak of the eschatological destruction of worldly wisdom. Prioritising the concluding Pauline passage of the De subiecto theologiae, KarlHermann Kandler has responded to Kurt Flasch's interpretation by arguing that Dietrich's philosophical treatises should be understood as preparations for his lost theological works. ${ }^{13}$ The major difficulty here is that we cannot assess a theological corpus that barely exists. Kandler's emphasis would do justice to the hypothetical nature of Dietrich's philosophical theology, but it does not sufficiently capture the critical edge of the rational necessity it wielded against the communiter loquentes. Dietrich was very willing, for instance, to promote several theses that were censured in 1277 (e.g., in the numbering of Denifle and Chatelain, articles 30, 43, 44, 54, 64, 70, 73, 84, 85, 92, 94, 95, 102, 115, and ${ }_{138-141) .114}$ But this does not mean was he using the Augustinian model of providence for purely naturalistic ends. Dietrich found support for his rationalism in Augustine and Aristotle together. For him, it is necessary to suppose that God acts according to reason, and to grasp the essentially ordered totality of the universe by beginning with the Aristotelian principle that each thing exists for the sake of its proper operation. ${ }^{115}$ In sum, while advocating for an integral and coherent pursuit of natural divine science according to its own lights, which can even challenge theological theses, Dietrich retained a scepticism that acknowledged the provisionality of its conclusions; they are necessary from our standpoint, they are the best the wayfarer has at their disposal, but there will come a time when this reasoning by conjecture will pass away. As his citation of 1 Corinthians 13:8 at the end of the De subiecto theologiae

\footnotetext{
112 According to Flasch, Dietrich von Freiberg, p. 205, the contradiction involved in positing necessary beings as hypotheses did not occur to Dietrich. I would instead propose that we regard it as one of Dietrich's most provocative methodological innovations.

113 Kandler, "Theologie und Philosophie"; id., "Theologische Implikationen".

114 K. Flasch, D'Averroès à Maître Eckhart. Les sources arabes de la 'mystique' allemande (Paris: Vrin, 2008), p. 96-97; D. Calma, "La connaissance réflexive de l'intellect agent. Le 'premier averroïsme' et Dietrich de Freiberg", in J. Biard, D. Calma, R. Imbach (eds), Recherches sur Dietrich de Freiberg, p. 63-105, at p. 76.

115 E.g., Dietrich of Freiberg, De animatione caeli, 1.2, p. 13, l. 10-14; 5.3, p. 16, l. 19 - p. 17, l. 30; 20.1, p. 3o, 1. 78-86; id., De intellectu et intelligibili, I.1.1, p. 137, 1. 3-10.
} 
implies ("Charity never fails; but whether there be prophecies, they shall fail; whether there be tongues, they shall cease; whether there is knowledge, it will be destroyed [scientia destruetur]"), it is in ethical life that a person is in direct contact with the reality that abides. In this respect, it is unfortunate that more attention has not been given to the influence of Albert's theological works on the De subiecto theologiae, for these seem to offer closer parallels to Dietrich's argument than Albert's commentaries on Aristotle. ${ }^{116}$

The uncompromising rhetoric of this Pauline conclusion was consistent with milder remarks made elsewhere in Dietrich's corpus, even though on first glance it might seem otherwise. Kurt Flasch has noted a tension between the De subiecto theologiae and a passage in the De cognitione entium separatorum, where Dietrich stated that separated souls retain some of the knowledge they acquired during their embodiment, in addition to their innate knowledge. ${ }^{117}$ Furthermore, as Dietrich made clear in De visione beatifica,

116 An exception to this is Trottmann, "La théologie des théologiens et celle des philosophes", p. 542-544, who has argued the De subiecto was also in agreement with Albert's account of the relation of metaphysics and theology in his theological works, according to which the reasoning about God as the first cause gives way to the free movement toward God and eschatological beatitude: "[Dietrich] est en cela fidèle à l'essentiel de l'enseignement de son maître". If this fragment indeed was related to Dietrich's lectures on the Sentences, then he may have been influenced by Albert's verdict that Aristotle did not pursue divine science in relation to a beatifying end beyond creatures. See Albert the Great, In I Sententiarum, ed. A. Borgnet, Opera omnia, vol. 25 (Paris: Vivès, 1893), d. 1, a. 4, p. 18b. In Albert's discussion of the transcendentals in the same commentary, he argued that Aristotle understood ens only as the final conception reached by an intellectual resolution and bonum only as a property of moving being, whereas the saints (sancti) treated being and the other transcendentals insofar as they flow from the first cause. See Albert the Great, In I Sententiarum, ed. A. Borgnet, Opera omnia, vol. 26 (Paris: Vivès, 1893), d. 46, a. 14, p. 450a, and the analysis of J. Aertsen, Medieval Philosophy as Transcendental Thought. From Philip the Chancellor (ca. 1225) to Francisco Suárez (Leiden: Brill, 2012), p. $183-186$.

117 Dietrich of Freiberg, De cognitione entium separatorum, 95.2-3, p. 259, l. 73 - p. 26o, 1. 86: Habitum est enim supra, quod anima separata habet eorum memoriam, quae experta est in vita. Sunt autem quidam habitus scientiales, in quibus adipiscendis indigetur experientia sensuali, ut sunt multae medicinae et perspectiva et aliae quaedam scientiae naturales. Hae scientiae seu habitus earum manent in anima separata virtute experientiae praecedentis, eadem ratione saltem, qua notitia aliarum rerum, quas expertae sunt, manent in eis, immo multo fortius ex eo, quod adiuncta ratione scientiali cum experientia fortificatur talis notitia in eis. De his autem scientiarum habitibus, qui sunt pure intellectuales, ut sunt scientiae arithmeticae et geometriae vel similes, sive habuerint eas in hac vita sive non habuerint, dicendum, quod huiusmodi habitus ex integro habent animae separatae secundum statum naturae suae non solum quoad talium artium principia, sicut aliquis possest dicere, verum etiam quoad ipsarum artium conclusiones. See Flasch, Dietrich von Freiberg, p. 511. 
voluntary providence is "the completion and consummation" of natural providence, ${ }^{118}$ and not its destruction. Here, as Flasch rightly observes, voluntary providence plays "a secondary role" in relation to the affirmations of natural providence. ${ }^{119}$

If we foreground Dietrich's hypothetical approach to the natural divine science of the philosophers, these apparent tensions can be resolved. We may begin by recalling a passage from the De dotibus corporum gloriosorum that echoed the argument about voluntary providence from the Devisione beatifica and clarified its meaning:

As to what pertains to the beatific vision of those who have glorified bodies, something must now be said that presupposes what has been said elsewhere and perhaps in more detail. Here one must first consider how the blessed soul or the glorified human being, with their beatific vision intact and unhindered, could progress toward some new natural cognition. The response to this is plain and clear because that blessed vision exceeds every natural cognition and differs from it generically. But those things that differ generically can exist together in the same thing, because they are not opposed to one another as contraries, just like quantity and quality that exist in the same subject. ${ }^{120}$

118 Dietrich of Freiberg, De visione beatifica, 4.3.2 (3-4), p. 114, 1. 8-21, cited in Berthold of Moosburg, Expositio, 129F, p. 182, l. 288-302: Et ad hoc, quod talis ordo causalis salvetur ex integro, quo formalitas causaliter determinetur ab una in aliam, rationabile est totam huius ordinis dispositionem inveniri in uno aliquo, et hoc est ens, quod participat intellectu, quo apprehendit quiditates rerum in suis propriis rationibus, quo intellectu secundum genus nihil est superius nisi intellectus separatus, qui intelligit per suam essentiam. Et in hoc attenditur quaedam immediatio inter hunc intellectum et illum. Unde possibile, immo rationabile est hunc superiorem fieri formam huius inferioris. Et dico rationabile esse hoc et non dico necessarium esse, quia huiusmodi non fit ex necessitate ordinis, qui attenditur in providentia naturali, sed contingit ex sola Dei gratia et bonis meritis, quod pertinet ad ordinem voluntariae providentiae, qui est complementum et consummatio ordinis providentiae naturalis, quem duplicem ordinem in universo distinguit Augustinus VIII Super Genesim.

119 Flasch, Dietrich von Freiberg, p. 574, n. 3 .

120 Dietrich of Freiberg, De dotibus corporum gloriosorum, 23.1-3, p. 286, 1. 66-74: De eo autem, quod pertinet ad beatam eorum [hominum habentium corpora gloriosa] visionem, nunc ultimo aliquid dicendum, salvis his, quae alibi dicta sunt, fortassis magis exquisite. Et primo hic considerandum, quomodo salva et non intercepta illa beata visione anima beata vel homo glorificatus possit progredi in aliquam novam naturalem cognitionem. Ad hoc patet responsio et est in promptu, quia illa beata visio excedit omnem naturalem cognitionem et differt etiam genere. Sed ea, quae differunt genere, compatiuntur se in eodem, quia sibi invicem non opponuntur contrarie, ut quantitas et qualitas, quae sunt in eodem subiecto. 
This plainly affirms that natural knowledge will persist and even progress for the saints after the Resurrection and will not interfere with their enjoyment of the beatific vision - an even stronger affirmation of the preservation of natural knowledge than what we saw in De cognitione entium separatorum.

This text also helps us reconcile the other two passages with the De subiecto theologiae because it shows that it is necessary to make distinction in Dietrich's views about natural knowledge, between the divine science of the philosophers (the target of the De subiecto) and natural knowledge in general (the subject of the passages from De cognitione and De dotibus). As the latter two passages show, the stable knowledge that the soul acquires while in its mortal frame will abide after death, as will its innate content that is recollected in its embodiment. What passes away is only the soul's imperfect and conjectural knowledge about the realities that are above its ken. For Dietrich, the soul's knowledge of the simple substances is imperfect because they do not have a quiddity or a definition, ${ }^{121}$ and thus cannot be known with the certainty of a demonstrative syllogism. The De subiecto is arguing that charity is more important for the wayfarer in this life than this partial knowledge, important though it is and even necessary within its own domain. Dietrich, in other words, was pleading for the deferral of the authority that the theologians would prefer to exert imminently on the divine science of the philosophers by suspending the laws and patterns of reason. His habitual caveats about the existence of separate intelligences and heavenly souls ("if they exist") are not a contradiction Dietrich failed to notice, but rather are a sign of his self-critical awareness of the greater framework within which natural and necessary reasoning about the separate substances occurs.

Berthold used the De subiecto theologiae fragment only once in the Expositio. He modified its terminology to describe the subject of Proclus' science and replaced some of the authorities cited by Dietrich with others. ${ }^{122}$ The universe

121 Dietrich of Freiberg, De quiditatibus entium, eds R. Imbach, J.-D. Cavigioli, in Opera omnia, vol. 3, 3.1-4, p. 101, l. 3- p. 103, l. 64 .

122 Berthold of Moosburg, Expositio, Expos. tit. I, p. 46, l. 319 - p. 47, l. 341 Cf. Dietrich of Freiberg, De subiecto theologiae, 3.5-6, p. 281, 1. 69-87: Et quia totus iste liber tractat de rerum divinarum universitate secundum processum eius a summo bono et regressum in ipsum, et hoc secundum dispositionem et proprios modos earum inditos ipsis rebus divinis ab eo, quod est divinum principaliformiter sive secundum causam, et hoc secundum ordinem providentiae naturalis, non iam proprie voluntariae, iuxta distinctionem Augustini VIII Super Genesim ad litteram, necesse est omnia convenire, de quibus hic tractatur, in una ratione subiecti, propter quam etiam ista philosophia est una scientia. Quod subiectum vocetur, sicut et vere est, bonum divinum, quod simpliciter et absolute causaliter seu principaliformiter convenit omnium primo principio, reliquis autem bonis, puta divinis per essentiam et per participationem, in attributione ad ipsum, et hoc quantum ad modos attributionis, 
of divine things (Dietrich had written: "the universe of beings") proceeds from and returns to God according to the orders of natural and voluntary providence. For Berthold, the Elementatio theologica concerns the domain of natural providence (as Dietrich himself implied) and, therefore, treats ens divinum according to the three modes of an essential order: God (bonum absolute causaliter seu principaliformiter), the gods (bonitates per essentiam), and their subordinate participants (bonitates per participationem). Instead of Dietrich's examples relating to health to explain the analogy of attribution (efficient, final, substantial) between creatures and God as ens divinum, Berthold cited two "rules" (regulae) of Hermes and two chapters from Avicebron's Fons vitae, which establish that God is the true foundation or ratio subiecti, for he is a "principle without principle", and "in comparison to him all substances are like accidents, and every accident is as nothing". ${ }^{123}$ This modification was not only doxographical. As we will recall, Dietrich gave only the examples of sacramental actions in persona Christi for the analogical relation of accidents to substance, forcing Berthold to give an argument from the natural order to explain the substantial dependency of created goods on the Good itself.

At first glance, it seems that Berthold has merely transposed Dietrich's argument into a Proclean context. Behind these more superficial modifications, however, was a more profound departure from his source. Berthold construed the difference of natural and voluntary providence in terms that he derived entirely from his reading of the Elementatio theologica and Dionysius, rather than follow Dietrich's elegant separation of pagan philosophy and revealed theology. In the Praeambulum especially we will see how Dietrich's mark of ownership (theologia nostra) in Berthold passed from Christian theology to the divine science of the Platonists. For Berthold, the ambitions of Dietrich's

quos distinguit Averroes super principium IV Metaphysicae, scilicet ut ad efficiens primum et finem ultimum nec non ut accidentia ad subiecti, cum Deus, qui est summum bonum, non solum sit 'principium sine principio, processus sine variatione, finis sine fine,' ut dicitur 7 regula Trismegisti, verum etiam 'Deus est, cuius comparatione substantia est accidens, accidens vero nihil' per 6 ibidem. Dicit autem substantiam quamcumque esse accidens ratione dependentiae eius ad primum, cui soli competit ratio subiecti, non ut existentis in potentia passiva, sed activa, qua sustentat, qui efficit universa, et de tali accidentis ratione loquitur Avencebrol libro III Fontis vitae cap. 36 et 54. Ex praedictis apparet, quod bonum divinum secundum ordinem providentiae naturalis est subiectum huius libri.

123 The same pairing of Hermes (Liber XXIV philosophorum, maxim 6) and Avicebron (Fons vitae, lib. III, c. 36 and c. 54) appears elsewhere: Expositio, 2 B (p. 84, 1. 74-77), with the regulae of Boethius, and $150 \mathrm{OG}$ (p. 127, l. 250-52). The agreement of Avicebron and Boethius in $2 \mathrm{~B}$ might have reinforced Berthold's strange stipulation that the De unitate et uno of "Boethius" (actually Gundissalinus) was completely excerpted from the Fons vitae $(1 \mathrm{D} ; 137 \mathrm{~B})$. 
philosophical theology could only be realised when it was translated back into the ancient Platonic science of the One and the Good. The influence of Thomas of York, who showed Berthold that the pagans had achieved a robust knowledge of God, meant that this focalisation of Dietrich's thought on Proclus necessarily entailed the abandonment of Dietrich's sceptical and hypothetical approach to reasoning about ens divinum within natural providence. If this Platonism demanded that we reason about the separate substances "not according to ourselves", then its rational conclusions had to receive the mind's assent if the exercise was to have its effect of liberating the soul from its captivity to its own abstractions. Berthold, in other words, sought not to elaborate a hypothetical cosmology, but to recover its perfect realisation in the distant past. This more fundamental shift was presupposed when, as we will see, Berthold rebranded Augustine's two orders of providence with Platonic equivalents: antarkia for natural providence and hierarchia for voluntary providence.

At the first mention of the twin orders of providence (gemina providentia) in the Expositio, without explaining the sources or meaning of the distinction, Berthold signalled that the familiar boundaries of nature and grace, of natural and voluntary providence, were breaking down:

These are the invisible things of God taken transitively, which are discussed most subtly in this Theological Elementation within the domain of natural providence. For there are also the invisible things of God of voluntary providence, such as the angels, which, as Proclus says in $\mathrm{On}$ the Existence of Evils, chapter 3, are 'the class that is the interpreter of the gods, existing in continuity with the gods. This class knows the mind of the gods and brings the divine will to light $[\ldots . .]^{1}{ }^{124}$

Where a reader of Ulrich or Dietrich would expect to find a Scriptural or Christian authority invoked to explain the nature of the entities in the order of voluntary providence, Berthold went directly to Proclus, who not only spoke about angels but identified them explicitly as those who reveal the divine will (elucidat divinam voluntatem), uttering forth the silence of the gods (pronuntians illorum silentium). For Berthold, what Dionysius and Proclus

124 Berthold of Moosburg, Expositio, Prol. 5-6, p. 13, l. 264-270: Ista sunt invisibilia Dei transitive accepta, de quibus in ista elementatione theologica subtilissime pertractatur, quantum pertinet ad providentiam naturalem. Sunt praeterea invisibilia Dei providentiae voluntariae, puta angeli, qui, ut dicit Proclus De malorum existentia 3 cap., sunt 'genus interpretativum deorum continuum existens dis. Et intellectum novit deorum et elucidat divinam voluntatem [...]'. Cf. Proclus, De malorum subsistentia, c. 3, §14, p. 194, l. 8-18. 
taught about the angels was effectively identical. ${ }^{125}$ In two other passages (Propositions 26 and 161), Berthold in fact clarified Dionysius using Proclus, to say that the angels, which are highest in the order of voluntary providence, immediately follow upon the primordial causes or "gods" rather than God himself. According to natural providence, wrote Berthold, the order of infinities (infinitates) immediately follows the gods, while in voluntary providence "the order of angels and especially the first and highest [the order of seraphim] is immediately conjoined outside the gods", as Proclus made clear and Dionysius implies (huic alludit Dionysius). ${ }^{126}$ An argument in $26 \mathrm{H}$ explains why Berthold used this verb alludit. Here he gave a number of references to passages in Dionysius that place the seraphim directly beneath the thearchy (thearchia); however (autem), he remarked, "If I cast the eye of consideration to natural providence, then the angels are continuous with the gods and not God himself, according to Proclus' intent in De malorum existentia". ${ }^{27}$ For Berthold, therefore, the seraphim are of course the highest in the order of voluntary providence. But these remarks also suggest he understood this order to be ontologically embedded within the order of natural providence. ${ }^{128}$ What this means is that, within the perspective of voluntary providence, the gods are regarded as effectively one with the Trinity. Dionysius could be said to "imply" this doctrine since, in Berthold's view, the term "thearchy" designates God and the primordial causes collectively. ${ }^{129}$ From the standpoint of natural providence, however, the gods are regarded as a separate phase of an essential order - they are the divine "according to essence", subordinate to God "according to cause" - and in this

125 Berthold of Moosburg, Expositio, 16E, p. 28, l. 168-17o.

126 Berthold of Moosburg, Expositio, 161C, p. 12, l. 34 - p. 13, l. 62: Verum quoad voluntariam providentiam ordo angelorum et specialiter primus et supremus immediate iungitur extra diis, sicut dicit auctor libro De malorum existentia [...]. Huic alludit Dionysius [...]. In the passage cited, however, Dionysius described the angelic order as circa Dei substantiam semper, et attente ipsi et ante alios sine medio unitum (De caelesti hierarchia, 6.2, 200D).

127 Berthold of Moosburg, Expositio, 26H, p. 158, l. 192 - p. 159, l. 213: Si autem ad providentiam naturalem oculum considerationis coniecero, tunc angeli sunt continui dis, non iam prime Deo secundum intentionem auctoris 3 cap. De malorum existentia [...]. The phrase is reminiscent of Augustine, De Genesi ad litteram viri.9.17 (oculus cogitationis attollitur), and is echoed elsewhere (e.g., Expositio, 9F, p. 175, l. 307-310).

128 On the ambiguous place of the angels in Dietrich's doctrine of gemina providentia, see Suarez-Nani, Les anges et la philosophie, p. 146.

129 Berthold of Moosburg, Expositio, Prol. 4, p. 11, l. 201 - p. 12, l. 217; 10A, p. 178, 1. 61-66: Quem etiam ordinem Dionysius II Epistula ad Gaium vocat 'thearchiam' et 'boni principatum,' super quem est prime Deus, qui et prime bonum; $113 \mathrm{~A}-\mathrm{B}, \mathrm{p} .34, \mathrm{l} .45^{-52}$ and p. $35,1.82-$ 83: Ista deitas thearchiae secundum Platonicos inexistit divinis per essentiam. [...] Unde etiam talis ordo sive numerus divinus a Dionysio vocatur thearchia. 
more discursive standpoint the seraphim would immediately follow "the gods", and God only mediately.

We have already noted the second and more striking example of Berthold's use of Proclus as an authority in the domain of voluntary providence. This is found in Proposition 114, the first subsection of which (114A) was discussed above relative to the philosophically acceptable and non-superstitious doctrine of polytheism shared by Hermes and the true followers of Plato. In $114 \mathrm{~B}$, Berthold turned to Ulrich's doctrine of divine providence to account for the different senses of the words deus and deitas: the Good unfolds its providence through the primordial causes (Ulrich: per fatum), and thereby shares "the dignity of causality and of divine cooperation" with secondary causes. ${ }^{130}$ Berthold then brings us immediately to the two domains of providence, since deus is said of participants "either by nature or by grace, according to the order of twofold providence". ${ }^{131}$ Discussing the order of grace or voluntary providence, Berthold first provided a lengthy citation of Dionysius (De caelesti hierarchia 12.3, 293B), on the saints who become participants of the divine by seeking to imitate God as much as possible. Immediately following this, Berthold argued that Proclus "makes the same point" (ad idem facit auctor) when he spoke about the cognition beyond intellect in De providentia et fato 8.32. ${ }^{132}$ Both passages on Proclus

130 Berthold of Moosburg, Expositio, 114B, p. 43, l. 92-10o.

131 Berthold of Moosburg, Expositio, 114B, p. 44, l. 117-119: Dicitur tamen hoc nomen 'deus' esse de participantibus aliquam proprietatem divinam, et hoc sive per naturam sive per gratiam, secundum ordinem duplicis providentiae, naturalis videlicet et voluntariae. The first two clauses come from Albert the Great, Summa theologiae, lib. I, tr. 6, q. 29, c. 1, a. 1, p. 216, l. 61-64. In this passage, Albert discussed acceptable meanings of participated divinity in Scripture, "the poets, and certain philosophers", namely, in Apuleius, the Liber de causis, Hermes, and the Timaeus. It is noteworthy that Berthold interpolated the distinction of natural and voluntary providence into Albert's mention of nature and grace.

132 Berthold of Moosburg, Expositio, 114B, p. 44, l. 117-128 and 135-140: Per gratiam, secundum quod dicit Dionysius 12 cap. Angelicae hierarchiae: 'Invenies autem, quod et deos theologia vocat et caelestes et super nos substantias, et apud nos Dei amicissimos mirabiles et sanctos viros (alia translatio: et quidem divinum secretum superessentialiter simul omnibus et remotum et supercollocatum et nullum ab eorum, quae sunt, simile nominari proprie et omnino valet. Verumtamen quaecumque et intellectualium et rationalium ad unitatem eius et qualiscumque virtus universaliter convertitur et ad divinas ipsius illuminationes, quantum possibile, incessabiliter extenditur secundum virtutem, si iustem dicere, divina imitatione et divina univocatione digna facta est) [...]?. Ad idem facit auctor De fato et providentia 8 cap. [...] ubi loquitur de cognitione animae super intellectum: 'Hanc, o amice, divinissimam enter operationem animae aliquis operans, soli credens sibi ipsi, scilicet flori intellectus, et quietans se ipsum non ab exterioribus motibus, sed ab interioribus, deus factus ut animae possibile, cognoscet solummodo, qualiter dii omnia indicibiliter cognoscunt singuli secundum li unum: 
as a theologian of voluntary providence (on angels and deification), we may note, were among the few singled out by Berthold with manicules in his copy of the Tria opuscula. ${ }^{133}$

Berthold's textual basis for bringing the pagan and Christian Platonists together on the doctrine of grace and deification was their common appeal

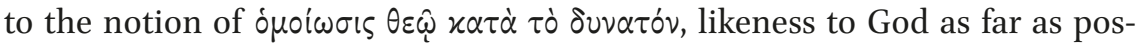
sible (Dionysius: convertitur ad divinas illuminationes quantum possibile [...] divina imitatione et divina univocatione digna facta est; Proclus: deus factus ut animae possibile). ${ }^{134}$ Berthold would have found this caveat (ut animae possibile) in each of the Tria opuscula. ${ }^{135}$ Along with this verbal agreement we may recall their shared doctrine of contemplation Berthold presented in Proposition 202, which was defined in terms of the ceaseless striving for the divine, the unification of the self, and conjunction with God through the unum animae: 136

Contemplation is the steadfast and unswerving extension of an intellectual substance, exceeding itself and all beings and non-beings unrestrainably, into the supersubstantial ray of divine shadows, as is meet and right. ${ }^{137}$

Loris Sturlese has observed that the standard ways of conveying the mediation of grace, in the Church and the sacraments, were not emphasised, let alone even mentioned by Berthold, and that the Dominican's stress in the Expositio fell rather on the difficulty of the philosophical effort involved in the ascent to God through the oblique motion. ${ }^{138}$ Berthold's passing references to the order of voluntary providence did not touch on these themes of sacramental grace. But in light of the foregoing considerations of the three motions of the soul and the two orders of providence, it seems we must admit yet again that for Berthold the philosophical effort itself, if it was to pass from discursivity of the

\footnotetext{
133 See Introduction, section 2, n. 74, above.

134 Plato, Theaetetus, 176b. Berthold of Moosburg, Expositio, 161C, p. 12, 1. 31-34, defined deification using Dionysius: deificatio sit ad Deum, sicut est possibile, assimilatio et unitio.

135 Proclus, De decem dubitationibus circa providentiam, q. 10, §64; De providentia et fato, c. 8, §32; De malorum subsistentia, c. 7, §24.

136 Berthold of Moosburg, Expositio, 202B, p. 184, l. 97-117. For Proclus, see Expositio, 202C, p. 186 , l. $15^{2-171 .}$

137 Berthold of Moosburg, Expositio, 202A, p. 181, l. 22-24: Contemplatio est substantiae intellectualis se ipsam et omnia existentia et non existentia excedentis irretentibiliter, firma et indeclinabilis ad supersubstantialem divinarum tenebrarum radium, sicut decet, extensio.

138 Sturlese, Homo divinus, p. 146-147.
} 
Elementatio to its higher end, required a form of divine assistance. ${ }^{139}$ The laborious investigation of the oblique motion is available to everyone, although Berthold has made it clear that following Plato's theorems earnestly will take a person along "a certain byway that is beyond the common path of reasonings". Returning briefly to Proposition 202, where all the proof-texts for the direct and circular motions are found, we will see that this definition of contemplation held for all three spiritual motions. By way of summary, then, let us return to Berthold's account of contemplation to see how the three motions and the two orders of providence are unified within a single progression.

Before citing the relevant passages from Dionysius and Proclus on contemplation, Berthold included the six kinds of contemplation discussed by Richard of St. Victor, which he had used tacitly in the gloss on Psalm 42 at the conclusion of the Prologus. He then cited several passages from Book v of the Beniamin maior, in which Richard outlined a threefold order of contemplation and subdivided each stage into the three causes that give rise to it and bring it to perfection. ${ }^{140}$ First is the enlarging of the mind (dilatatio mentis), which does not pass beyond the limit of human industry, and is subdivided into teaching, mental exercise, and attention (traditio, exercitatio, attentio), which are its causes. Second comes the lightening of the mind (sublevatio mentis), corresponding to the liveliness of intelligence (intelligentiae vivacitas), when the mind is inspired and illumined by heavenly light, and is sometimes (aliquando) elevated above knowledge, above human industry, and above nature (supra scientiam, supra industriam, supra naturam). Here the mind sees realities that are above it, but cannot yet free itself from its habitual weight.

The third and highest stage is the dispossession of the mind (alienatio mentis), which is brought about by the abundance of devotion, wonder, and exultation (magnitudo devotionis, admirationis, exultationis). The abundance of devotion, through the interplay of the soul's fervent desire and divine assistance, makes it receptive to a divine gift: "when the mind burns excessively with the flame of heavenly desire, it becomes worthy to see something from a divine revelation, so that it is helped to reach those theoretical ecstasies". ${ }^{141}$

139 This was not itself entirely novel. According to Thomas Aquinas, God, if he pleases, grants sanctifying grace to the pagan philosophers in view of their realisation of a natural capacity as rational creatures to love God above all else. See A. Oliva, "La contemplation des philosophes selon Thomas d'Aquin", in Revue des sciences philosophiques et théologiques 96(2012), p. 585-662, at p. 6o5-612.

140 Berthold of Moosburg, Expositio, 202B, p. 183, l. 64 - p. 184, l. 95.

141 Berthold of Moosburg, Expositio, 202B, p. 183, l. 79-81, citing Richard of St. Victor, Beniamin maior, lib. v, c. 8, ${ }_{177}$ D-178A, p. 266, l. 59-61: saepe enim in mente humana agitur, ut, dum 
The abundance of wonder is kindled by the vision it receives of a reality that is beyond all hope and conception (aestimatio); this wonder arouses attention, and with attention comes thinking (cognitio). In this attentiveness, as the mind climbs to higher and higher realities (dum mens humana semper ad altiora crescit), it eventually reaches a point where it leaves the bounds of human capacity altogether (dum diu crescendo tandem aliquando humanae capacitatis metas excedit). This is finally perfected in the abundance of joy and the exultation in which the mind goes out of itself entirely.

In Proposition 202, Berthold juxtaposed Richard's two classifications of contemplation, the six "genera" and the three "modes" (dilatatio, sublevatio, alienatio), without explicitly establishing any correlation between them. For more recent interpreters of Richard, there is a sense in which the three modes describe the qualities common to all six genera. As Jean Châtillon has put it, the sixfold division describes the objects of contemplation and the faculties that apprehend them, whereas the three modes correspond to the different states of the mind as it contemplates its object. ${ }^{142}$ But there is another sense, as Châtillon also observed, in which the end of the Beniamin maior, with these three modes, returned to the sixfold classification from its beginning, such that dilatatio would refer to the first four degrees (in imagination and according to imagination; in imagination according to reason; in reason according to imagination; in reason according to reason), which are all contemplative activities within the bounds of human effort; sublevatio to the fifth (above reason, but not beyond reason), when the mind is inspired and illumined by God, but it has not yet left its habitual ways behind; and alienatio to the sixth (above reason, and seems to be beyond reason), when the mind is totally absorbed in devotion, wonder, and praise. ${ }^{143}$

Both interpretations are available to a reader of the Expositio from the materials taken from Richard in 202A-B. The second option gains additional confirmation in view of the meditation on Psalm 42 in the Prologus. We can now see just how perceptively Berthold merged the sixfold and threefold models around the precise terms used by the Psalmist and in Lombard's gloss. ${ }^{144}$

nimio caelestis desiderii incendio uritur, aliquid ex divina revelatione videre mereatur, unde ad illos theoricos excessus adiuvetur.

142 J. Châtillon, "Les trois modes de la contemplation selon Richard de Saint-Victor", in Bulletin de littérature ecclésiastique 41(1940), p. 3-26, at p. 23; see also p. 14 and 16, and the studies cited there.

143 Châtillon, "Les trois modes", p. 23-26. This interpretation is followed by J. Grosfillier, "Introduction", in Richard of St. Victor, De contemplatione (Beniamin maior), p. 46.

144 Berthold of Moosburg, Expositio, Prol. 2o, p. 34, l. 953-963. See 1.3, n. 9o-91, above. 
According to Berthold, effudi, id est dilatavi, animam meam corresponds to the summit of the search for God in the fourth kind of contemplation and the desire to pass over into the fifth (dilatavi animam meam ad intelligendum supra se ipsam). The fifth kind or the eye of intelligence that beholds the simple Form would align with the second mode, the sublevatio mentis, when the intelligence is inspired and illuminated with a revelation $(202 \mathrm{~B}$ : intelligentia humana divinitus inspirata et illo caelesti lumine irradiata), and sometimes passes beyond knowledge, human industry, and nature. Nevertheless, it remains weighed down to some extent because it is still reflexive (Prol. 20: ut quaereret Deum intelligentia secundum rationem). The sixth kind of contemplation, the entry into the primordial causes or "house of God", would align with the three causes of third and highest mode (alienatio mentis), especially wonder (ingrediar per unum animae in locum tabernaculi admirabilis) and praise (in voce exultationis).

If we read this synthesis from the Prologus back into the citations from Richard in $202 \mathrm{~B}$, we can see clearly how the dynamics of nature and grace unfold in the soul's ascent to God through a continuous process of contemplation that embraces the distinct activities of all three spiritual motions. Berthold's penultimate citation from Richard remarked that some have tended to speak about "contemplation" and "speculation" as if they were synonymous. Strictly speaking, however, contemplation occurs when one no longer sees the truth through a mirror (per speculum) but unveiled and without any trace of shadow. ${ }^{145}$ Speculation, then, corresponds to the first four kinds of contemplation which, in the gloss on Psalm 42, relate to the search for God in the material world and in the soul. We might say that these speculative stages are presupposed by the science of the Elementatio, as Berthold's discussion of physics and quadrivial science (duplex indagatio) from Albert's Metaphysics commentary implied, and do not fall within its purview in the strict sense. The mode of dilatatio mentis, however (corresponding to the fourth kind), when the mind has prepared itself to the extent it is able and yet still desires to pass from knowing "in reason according to reason" to intelligentia, would correspond precisely to the laborious study of Proclus' propositions in the oblique motion, which constitute a spiritual exercise leading the soul "beyond the common path of reasonings". The Platonic theorems, in other words, prepare the mind for the passage from speculation, integuments or veils, to contemplation in the strict sense. Berthold insisted that these theorems should be revealed only to those

145 Berthold of Moosburg, Expositio, 202B, p. 183, l. 90-92, citing Richard of St. Victor, Beniamin maior, lib. v, c. 14, 187A-B, p. 558, 1. 108-111: aptius tamen et expressius speculationem dicimus, quando per speculum cernimus; contemplationem vero, quando veritatem sine aliquo involucro umbrarumque velamine in sui puritate videmus. 
who have been attracted by the most longed-for unveiled image of truth. ${ }^{146}$ Therefore, the oblique motion pursued through the Elementatio should be seen as the highest activity a person can undertake by their own effort - that is, the highest kind of "speculation" or dilatatio mentis that "enlarges" the soul through the three causes of teaching (traditio, where Richard had "art", ars), exercise (exercitatio), and attention (attentio). It is a form of contemplation in the broad sense that prepares the way for imageless contemplation in the strict sense.

As Berthold's final citation of Richard in $202 \mathrm{~B}$ stated, the two higher modes (sublevatio and alienatio), unlike dilatatio, should both be understood as gifts from God:

No one from their own powers expects such an exultation or lightening of the heart or ascribes it to their merits. It is certain that this is the result not of human merit, but of a divine gift. ${ }^{147}$

These two highest modes, which correspond to contemplation in the strict sense because they are beyond veils and images, align with the fifth and sixth levels identified in the Prologus as the activities of intelligentia and the unum animae. Berthold thus invited his reader to interpret the Proclean and Dionysian proof-texts for the circular and direct motions of the soul, cited in the remainder of the commentary on Proposition 202, in light of Richard of St. Victor's theory of contemplation. At no point did he express any hesitation about Richard's theory, nor did he indicate that it diverged from the shared view of Proclus and Dionysius: on the contrary, all of them were describing contemplation as it can be realised in this life (contemplatio viae).

We may deduce from this that the vision of pure Form by intelligentia in the sublevatio mentis corresponds to the intellectus adeptus of $123 \mathrm{D}$. If the

146 Berthold of Moosburg, Expositio, Expos. tit. K, p. 48, l. 389-391: [...] veritatis ipsius revelata desiderantissimaque imagine pertrahuntur. Hi soli digni sunt, ut eis sapientiae, quae in ista elementatione theologica continetur, dignitas exeratur. Cf. Gilbert of Poitiers, Expositio in Boecii librum de bonorum ebdomade, prol., n. 7, p. 184, l. 32-38.

147 Berthold of Moosburg, Expositio, 202B, p. 184, l. 93-95, citing Richard of St. Victor, Beniamin maior, lib. v, c. 15,187 C, p. 558, l. 4-6: Nemo autem tantam cordis exultationem vel sublevationem de suis viribus praesumat vel suis meritis ascribat. Constat hoc sane non meriti humani, sed muneris esse divini. This is not inconsistent with Richard's earlier statement that sublevatio occurs through the combination of human industry and grace (Beniamin maior, lib. v, c. 2, 17oB, p. 508, l. 17-19). Châtillon, "Les trois modes", p. 19, observes, that the passive verbs used to describe this mode at Beniamin maior, lib. v, c. $4,{ }_{172} \mathrm{D}$ (inspirata and irradiata) clearly put the initiative on the side of grace. 
intellectus adeptus should indeed be regarded as the lowest phase of this highest level of the human modes of knowing in $123 \mathrm{D}$, its activity was identified clearly as such in the gloss on Psalm 42 in the Prologus as the fifth kind of contemplation, "in intelligence according to reason". This would follow inasmuch as the immediate relation of agent and possible intellects still implies the downward facing operation of intelligentia as it relates to the ratio universalis or possible intellect. Finally, alienatio corresponds to the non-reflexivity of the unum animae, which is the higher phase of the same level in ${ }_{123} \mathrm{D}$. Therefore, whereas the oblique motion corresponds to the dilatatio mentis, the circular and direct motions, each in their own way, culminate in the sublevatio and alienatio mentis - one begins from within, the other from without, but both depend on a concourse of the mind's attention and enlargement, fervent desire, and both are received as a divine gift or grace. This, for Berthold, was the unanimous doctrine of contemplation shared by Proclus, Dionysius, and the Christian doctors.

This incorporation of both registers of nature and grace in the Platonic divine science on the basis of their common contemplative doctrine was assumed by Berthold when he translated the doctrine of natural and voluntary providence into the Platonic terminology of self-sufficiency (antarkia) and hierarchy (hierarchia). According to Berthold, in Proposition 9 Proclus proved the existence of self-sufficient (antarkes) principles that are perfect through themselves. This corrected the view of Avicenna and Al-Ghazali, who placed self-sufficiency beneath perfection because they defined sufficiency as something that is acquired after a prior state of imperfection. ${ }^{148}$ With Eustratius and Dionysius, Berthold maintained that what is self-sufficient always has its inherent good perfectly (cui bonum perfecte ingenitum est), requiring nothing outside itself. These self-sufficient principles will play a pivotal role in Berthold's cosmology, where "secondary founts", as recipients of "the superperfect", "supersufficient", "superabundant" efficient causality of the Good, have in and from themselves "the plenitude of their own goodness" as formal causes, and therefore can exercise proportional "superabundant" causality within their own order. ${ }^{149}$ In Proposition 10, Berthold coined the term antarkia to define precisely (stricte) the order of gods or "per se goodnesses". 150 The immaterial orders beneath the gods are self-sufficient to greater or lesser degrees;

\footnotetext{
148 Berthold of Moosburg, Expositio, 9A, p. 167, l. 18 - p. 168, 1. 36.

149 Berthold of Moosburg, Expositio, 9B, p. 169, l. 102-105: supersufficiens bonum est duplex, quia vel est tale simpliciter vel in genere, quod etiam magis proprie dicitur supersufficiens virtus vel ens vel vita etc., cum talia determinent bonum ad quoddam bonum.

150 Berthold of Moosburg, Expositio, 10A, p. 177, l. 31-35.
} 
they are all regarded as beings that exist like species (entia secundum speciem), spanning "the order of infinities" down to "intellectual hypostases", which are all "self-sufficient by themselves entire but not entirely" (se totis licet non totaliter), meaning that they are self-sufficient in substance, power, and operation, but are constituted out of a plurality of formal principles. Souls, finally, are self-sufficient in their substance but not in their operation. All these entities are self-sufficient (antarkes) by analogy to the gods. ${ }^{151}$

According to Berthold, hierarchia is to God and the gods in voluntary providence what antarkia (the order of self-sufficient, per se principles) is in natural providence. ${ }^{152}$ When commenting on the term deificatus in the Elementatio and, more rarely, when confronted with Proclus' mentions of intellectus divinus (e.g., 181D), Berthold relied principally on a pair of Dionysian texts which associate "hierarchy" with "deification":

De ecclesiastica hierarchia 1.3, 376A: 'Deification is assimilation and union with God, as far as possible' or, according to the other translation, 'likeness and unity' ('Deificatio est ad Deum, sicut est possibile, et assimilatio et unitio'vel secundum aliam translationem 'similitudo et unitas').

De caelesti hierarchia 3.2, 165A: The goal of hierarchy is assimilation and union with God, as far as possible (Intentio igitur hierarchiae est ad Deum, sicut est possibile, assimilatio et unitio)..$^{153}$

Thus it was certainly not the case that Dionysius for Berthold was only an authority in voluntary providence, although he sometimes spoke like "a theologian,, ${ }^{154}$ or that Proclus only had insights into the order of natural providence: Dionysius transmitted the Platonic doctrine of the Good and the primordial causes as the "thearchy"; Proclus, more rarely, discussed the angels and the outlines of a notion of hierarchy and deification by participation. This unification of both orders of gemina providentia in the Platonic divine science

\footnotetext{
151 Berthold of Moosburg, Expositio, 9B, p. 170, l. 129 - p. 171, l. 147; 9E, p. 173, l. 214-218, and p. 174 , l. 281 - p. 175 , l. 295.

$15^{2}$ Berthold of Moosburg, Expositio, 10A, p. 179, 1. 99-102: Ex praedictis apparet differentia inter antarkiam et hierarchiam, quia antarkia est ordo divinus secundum condiciones supra positas in description emanans a Deo iuxta dispositionem providentiae naturalis; hierarchia vero est ordo divinus emanans a Deo iuxta dispositionem providentiae voluntariae.

153 The adjective deificatus occurs in Propositions 135, 138, 153, 16o. Berthold cited De ecclesiastica hierarchia, 1.3, 376A, in the following propositions: 121B, 129B (Proclus: exdeatam

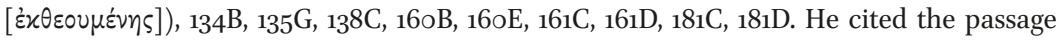
from De caelesti hierarchia, 3.2, $165 \mathrm{~A}$, three times: $10 \mathrm{~A}, 145 \mathrm{~A}, 153 \mathrm{~F}$.

154 Berthold of Moosburg, Expositio, 5B, p. 115, l. 98 - p. 116, l. 13 o.
} 
also had an exegetical advantage, which we have just witnessed. The relationship of proportionality between the two orders enabled Berthold to apply texts from Dionysius about hierarchy to the order of natural providence. ${ }^{155}$ Even if the Elementatio theologica did not concern voluntary providence, Berthold went out of his way to show that Proclus' authority extended there as well, just as Dionysius did to the order of natural providence, and that Platonism itself transcended the divide of pagan and Christian, nature and grace.

155 See, for example, Berthold of Moosburg, Expositio, 14oE, p. 41, l. 103-136; 156A, p. 169, l. 12 21; 156D, p. 172, l. 130 - p. 173, l. 166; 158A-B, p. 184, l. 10 - p. 185, l. 35; 162G, p. 21, l. 159-171; 163D, p. 28, l. 131-137; 165F, p. 41, l. 114 - p. 44, l. 175; 177I, p. 185, l. 386. 